NBER WORKING PAPERS SERIES

\title{
GROSS JOB CREATION, GROSS JOB DESTRUCTION AND EMPLOYMENT REALLOCATION
}

Steve J. Davis

John Haltiwanger

Working Paper No. 3728

\author{
NATIONAL BUREAU OF ECONOMIC RESEARCH \\ 1050 Massachusetts Avenue \\ Cambridge, MA 02138 \\ June 1991
}

This paper is part of NBER's research programs in Economic Fluctuations and Labor Studies. Any opinions expressed are those of the authors and not those of the National Bureau of Economic Research. 
NBER Working Paper \#3728

June 1991

GROSS JOB CREATION, GROSS JOB DESTRUCTION
AND EMPLOYMENT REALLOCATION

\begin{abstract}
This study measures the heterogeneity of establishment-level employment changes in the U.S. manufacturing sector over the 1972 to 1986 period. We measure this heterogeneity in terms of the gross creation and destruction of jobs and the rate at which jobs are reallocated across plants. Our measurement efforts enable us to quantify the connection between job reallocation and worker reallocation, to evaluate theories of heterogeneity in plant-level employment dynamics, and to establish new results related to the cyclical behavior of the labor market.
\end{abstract}

Steve J. Davis

Graduate School of Business

University of Chicago

Chicago, IL 60637 and
John Haltiwanger Department of Economics University of Maryland College Park, MD 20742

NBER 


\section{Introduction}

This paper measures the heterogeneity of establishment-level employment changes in the U.S. manufacturing sector over the 1972 to 1986 period. We measure this heterogeneity in terms of the gross creation and destruction of jobs and the rate at which jobs are reallocated across plants. Our measurement efforts enable us to quantify the connection between job reallocation and worker reallocation, to evaluate theories of heterogeneity in plant-level employment dynamics, and to establish new results related to the cyclical behavior of the labor market.

Our empirical work exploits a tremendously rich data set with approximately 860,000 annual observations on 160,000 manufacturing establishments. The data are longitudinal and include observations on all manufacturing establishments sampled in the Annual Survey of Manufactures between 1972 and 1986. The combination of establishment-level longitudinal data, high frequency observations, a fifteen-year sample, and comprehensive coverage of the manufacturing sector provides an excellent basis for developing the implications of heterogeneity in establishment-level employment dynamics.

A key aspect of our study is its focus on gross job flows as opposed to gross worker flows. Previous studies have documented the tremendous gross worker flows across labor market states (i.e., employment, unemployment, out of the labor force) and high worker turnover rates. ${ }^{1}$ In the absence of evidence from longitudinal establishment data, it has been difficult to determine whcther large gross worker flows primarily reflect temporary layoffs and recalls plus continual sorting and resorting of workers across a given set of jobs or, alternatively, whether a large portion of worker turnover is driven by the destruction and creation of employment opportunities.

The results that emerge from our study are striking. Based on March-to-March establishment-level employment changes, we calculate that manufacturing's rates of gross job creation and destruction averaged $9.2 \%$ and $11.3 \%$ per year, respectively. We show that these figures reflect simultaneously high rates of job creation and destruction within narrowly defined sectors of the economy, e.g., four-digit industries. The impressive magnitude of gross job creation and destruction has been documented before, perhaps most convincingly at high frequencies by Leonard (1987) and at low frequencies by Dunne, Roberts and Samuelson (1089b).

Summing the rates of gross job creation and destruction yields our measure of the job reallocation rate, i.e., the rate at which employment positions are reallocated across 'See Clark and Summers (1079), Abowd and Zellner (1985), Poterba and Summers (1986), Lilien (1980), Hall (1082), Darby, Haltiwanger and Plant (1985), Akerlof, Rose and Yellen (1988), and Blanchard and Diamond (1990). 
establishments. The high rates of job reallocation found in this paper indicate that the reshuffling of employment opportunities across plants is one of the most important reasons that workers change employers or transit between employment and joblessness. Combining information from the LRD and the Current Population Survey, we calculate bounds on the fraction of worker reallocation accounted for by job reallocation. Our calculations reveal that $35-56 \%$ of all worker reallocation between employers or between employment and joblessness arises to accommodate shifts in the distribution of employment opportunities across work sites.

Two other findings documented below provide insight into the character of the worker reallocation associated with job reallocation. One finding is that most of annual job creation and destruction reflects persistent establishment-level employment changes. For example, $73 \%$ of the jobs created between March 1974 and March 1975 still existed in March 1976, and $72 \%$ of the jobs lost in the 1974-75 interval were still lost in March 1976. The average one-year persistence rates for annual job creation and destruction are $68 \%$ and $81 \%$, respectively. This persistence indicates that the bulk of annual job creation and destruction cannot be implemented by temporary layoff and recall policies. A second finding is that job destruction is highly concentrated - only $23 \%$ is accounted for by establishments that shrink by less than twenty percent over the span of a year. This finding indicates that the bulk of job destruction cannot be accommodated by normal rates of worker attrition. Taken together, the concentration and persistence results imply that job reallocation is typically associated with long-term joblessness and/or worker reallocation across employers.

The impressive magnitude of job reallocation and its bearing on worker reallocation lead us to inquire into the sources of heterogeneity in establishment-level employment changes. We document strong relationships between the intensity of job reallocation and observable plant characteristics like age, size and ownership type (single-unit versus multiunit firm). We also draw on several theories of plant-level heterogeneity and dynamics to identify reasons for simultaneous job creation and destruction within narrowly defined sectors of the economy. Guided by these theories, we quantify the contribution of various sources of heterogeneity to total job reallocation and to variation in job reallocation across groups of establishments defined in terms of industry, region, age, size and ownership type.

One prominent theory of heterogeneity in plant-level employment dynamics stresses the selection effects associated with passive learning about initial conditions. ${ }^{2}$ We develop a procedure for estimating the fraction of total job reallocation accounted for by this source 2See Jovanovic (1982), Lippman and Rumelt (1982), and Pakes and Ericson's (1990) version of the Jovanovic model. 
of heterogeneity in plant-level employment dynamics. The procedure combines information on the distribution of employment by plant age and the rate of job reallocation by plant age with simple and plausible identifying assumptions. Despite the attention that these theories have received in recent empirical work, ${ }^{3}$ we find that passive learning about initial conditions accounts for only $11-13 \%$ of observed levels of job reallocation. In results more favorable to this type of theory, we find that leaning about initial conditions accounts for roughly one-third to one-half of the differences in job reallocation rates across groups of plants defined in terms of industry, size, region and ownership type.

Long traditions in labor and industrial economics view plants within industries, regions or employer size classes as relatively homogeneous. Theories of vintage effects view plants as relatively homogeneous within age groups. These perspectives suggest an explanation for high rates of job reallocation as the natural consequence of continually occurring sector-specific shocks, where sectors are defined in terms of industry, region, size or age. To evaluate this explanation, we compute the fraction of excess job reallocation accounted for by between-sector employment shifts. Excess job reallocation is defined as total job reallocation minus the minimum amount required to accommodate the net change in cmployment. Remarkably, we find that essentially none of the excess job reallocation in U.S. manufacturing can be accounted for by employment shifts among two-digit industries, Census geographic regions, eight age classes or five size classes. Even when we define sectors in terms of $\mathbf{4 5 0}$ four-digit manufacturing industries, between-sector employment shifts account for a mere $12 \%$ of excess job reallocation. Similar results hold when we define sectors in terms of both two-digit industry and either age, size, region or ownership type.

The inability of either sectoral shock theories or theories that stress learning about initial conditions to account for observed rates of job reallocation leads us to the following conclusion: Any successful explanation for the magnitude of job reallocation must also explain why simultaneously high rates of job creation and destruction occur among mature plants in narrowly defined sectors of the economy.

The impressive magnitude of job reallocation and its bearing on worker reallocation also lead us to inquire into the connection between the business cycle and the intensity of job reallocation. In this regard, a key finding is that the job reallocation rate exhibits significant countercyclic time variation. The March-to-March job reallocation rate for the manufacturing sector ranges from a low of $17 \%$ in 1980 to a high of $23 \%$ in 1975 and 1983. The simple correlation between net employment growth and the job reallocation rate is -0.57 .

${ }^{3}$ See Evans (1987ab), Hall (1987), Dunne, Roberts and Samuelson (1989a), and Pakes and Ericson (1990). 
We carry out several empirical exercises designed to address the question of why the job reallocation rate fluctuates countercyclically. These exercises establish two important sets of results. First, the countercyclic behavior of job reallocation reflects time variation in the magnitude of idiosyncratic plant-level employment movements, not sectoral differences in the mean employment responses to aggregate disturbances. Second, patterns of time variation in job reallocation intensity differ sharply by plant age, size and ownership type. Job reallocation rates among young (0-9 years), small (1-249 employees), and single-unit plants exhibit no systematic relationship to the cycle. Job reallocation rates among older, larger and multi-unit plants exhibit pronounced countercyclic patterns of variation.

These results enable us to discriminate between macroeconomic theories that cannot explain the observed cyclical behavior of job reallocation and theories that potentially can. We conclude that standard macrocconomic theories that specify homogeneous firms or homogeneous firms within sectors cannot account for the time variation in job reallocation intensity. Nor can cyclic movements in job reallocation intensity be explained by theories that treat the idiosyncratic component of firm-level employment behavior as orthogonal to the business cycle. As we discuss below, theories that stress the frictions associated with the reallocation of workers and jobs across employers imply potentially important interactions between aggregate employment growth and the pace of reallocation. Blanchard and Diamond (1989, 1990), Davis and Haltiwanger (1990), and Caballero (1990) develop theories of this sort that can explain some of the cyclical job flow findings in this paper.

We turn now to a description of the data and the gross job flow measures that we use in this study.

\section{Data and Measurement}

\section{A. The Longitudinal Research Datafile}

This study exploits annual, plant-level employment observations in the Longitudinal Research Datafile (LRD). The LRD sampling frame encompasses all U.S. manufacturing establishments with five or more employees. These establishments account for ninety-nine percent of manufacturing employment, based on tabulations from either the Census of Manufactures or County Business Patterns.

The LRD is basically a series of contiguous five-year panels with annual data on many manufacturing establishments, plus Census-year data on the universe of manufacturing establishments. Census years in the LRD are 1967, 1972, 1977, and 1982 - annual data are available from 1972 to 1986 . From the Census-year universe, the Bureau draws a sample of establishments that are then surveyed during five successive years. This five-year panel, which commences two years after a Census year, comprises the sample of establishments 
that makes up the Annual Survey of Manufactures (ASM). New establishments are added to the panel as it ages to incorporate births and to preserve the representative character of the panel. In 1977, the LRD included roughly 70,000 out of the 360,000 manufacturing establishments. These sampled establishments accounted for $76 \%$ of manufacturing employment.

With respect to the five-year ASM panels, establishments fall into three broad groups. As noted, the group containing establishments with fewer than five employees is excluded from the sampling frame. A second group of establishments is included in the panel with certainty. For the 1979-83 panel, for example, the certainty group includes all establishments with 250 or more employees during the 1977 Census year. This certainty threshold is lower in some industries, and many establishments are included with certainty based on other criteria. Taken as a whole, the certainty cases account for about two-thirds of manufacturing employment during the 1979-83 period. Establishments that fall into neither of the first two groups are sampled with probabilities proportional to a measure of size determined for each establishment from the preceding Census. Sampling probabilities for non-certainty establishments range from 1.000 to 0.005 . We use sample weights, equal to the reciprocals of the sampling probabilities, whenever we aggregate over establishments.

Some, but not most, of the non-certainty establishments appear in contiguous panels. Thus, our ability to link establishment-level observations across paneis ranges from excellent for large establishments to quite poor for the smallest establishments. This observation implies that accurate measurement of gross employment changes is more difficult in the first year of each panel. While it is possible to construct continuous series for basic measures of job creation and destruction, and we have done so in Davis and Haltiwanger (1990), some of the cross-tabulations presented below cannot be constructed for the first year of a panel. Hence, we typically calculate the gross and net change measures reported in this paper from a sample that excludes 1974, 1979 and 1984.

Several key features of the LRD enable us to largely overcome the selection and measurement problems that have hampered most previous attempts to estimate gross rates of job creation and destruction from plant-level or firm-level data. In this regard, the LRD's key features are the comprehensive scope of its sampling frame for a major sector of the U.S. economy, large probability-based samples that minimize sampling error, the incorporation of births into ongoing panels, a careful distinction between firms and establishments, and a careful distinction between ownership transfers and the birth and death of establishments. Among U.S. studies on job creation and destruction, Dunne, Roberts and Samuelson (1989b) provide the only other measurements based on a data 
set with similar virtues. Their work exploits the Census-year observations in the LRD to calculate five-year job creation and destruction rates. ${ }^{4}$

\section{B. Measurement of Gross Job Creation, Destruction, and Reallocation}

We now introduce some notation and define measures of establishment size and growth rate. We then plot the empirical growth rate density and relate it to job creation and destruction measures. We also describe the connection between these measures and measures of worker and job reallocation.

We measure the size of establishment $e$ at time $t$, denoted by $x_{e t}$, as the simple average of establishment employment at time $t$ and $t-1$. Sector size is defined analogously. We define the time-t growth rate of establishment $e$, denoted by $g_{e t}$, as the change in establishment employment from $t-1$ to $t$, divided by $x_{e t}$. This growth rate measure is symmetric about zero, and it lies in the closed interval $[-2,2]$ with deaths (births) corresponding to the left (right) endpoint. A virtue of this measure is that it facilitates an integrated treatment of births, deaths and continuing establishments in the empirical analysis. The $g$ measure is monotonically related to the conventional growth rate measure, and the two measures are approximately equal for small growth rates. ${ }^{5}$

Figures 1.A and 1.B plot frequency distributions for the establishment growth rate observations in our eleven-year sample. Figure 1.A depicts the shape of the empirical density over the 677,000 annual observations on $g_{e t}$. Figure 1.B depicts the shape of the empirical density over the size-weighted observations on $g_{e t}$. Both the weighted and unweighted densities are slightly asymmetric with central peaks in the interval surrounding zero and endpoint spikes corresponding to births and deaths.

On an unweighted basis, $25 \%$ of all manufacturing establishments experienced a growth rate in the interval $(-.05, .05)$, and $46 \%$ experienced a growth rate in the interval $(-.15, .15)$. Births and deaths account for $14 \%$ of annual growth rate observations on manufacturing establishments. The mass of the size-weighted distribution is much more concentrated about the center and much less concentrated in the tails. On a size-weighted basis, $29 \%$ of the annual growth rate observations fall in the interval $(-.05, .05)$, and $63 \%$ fall in the interval $(-.15, .15)$. Births and deaths account for only $2.4 \%$ of all size-weighted

${ }^{4}$ Davis and Haltiwanger (1989) discuss the weaknesses in other data sets that have been used in U.S. studies of job creation and destruction. For a full discussion of data quality issues pertaining to our use of the LRD, see Davis, Haltiwanger and Schuh (1990).

${ }^{3}$ Let $G$ be the change in employment divided by lagged employment, i.e., the conventional growth rate measure. The two growth rate measures are linked by the identity $G \equiv$ $2 g /(2-g)$. 
growth rate observations. ${ }^{6}$ Evidently, establishment turnover and employment volatility are sharply declining functions of establishment size in our sample, a result that is consistent with work by Evans (1987ab), Hall (1987), Dunne, Roberts and Samuelson (1989ab), and others.

The gross job flow measures investigated in this paper have a simple relationship to the size-weighted frequency distribution of establishment growth rates. We calculate gross job creation by summing employment gains at expanding and new establishments within a sector. Similarly, we calculate gross job destruction by summing employment losses at shrinking and dying establishments within a sector. To express these measures as rates, we divide by sector size. Introducing some additional notation, we can write gross job creation and destruction rates in sector $s$ at time $t$ as

$$
\begin{aligned}
& \text { POS }_{s t}=\sum_{\substack{t \in E_{t: t} \\
t e t>0}}\left(\frac{x_{e t}}{X_{e t}}\right) g_{e t}, \quad \text { and } \\
& N E G_{a t}=\sum_{\substack{i \in E_{j t} \\
i t<0}}\left(\frac{x_{e t}}{X_{s t}}\right)\left|g_{e t}\right|,
\end{aligned}
$$

where $E_{s t}$ is the set of establishments in $s$ at $t .^{7}$ As these formulas indicate, the sizeweighted frequency distribution determines the weight to attach to each growth rate value in the calculation of job creation and destruction rates.

Two remarks are helpful in thinking about our job creation and destruction measures. First, it seems apparent that year-to-year changes in establishment-level employment are largely induced by changes in desired establishment size rather than by temporary movements in the stock of unfilled positions. For this reason, $P O S_{91}$ and $N E G_{a l}$ directly reflect the reallocation of employment positions or jobs, and not the reallocation of workers. Of course, one motivation for our research is that the reallocation of jobs partly drives the reallocation of workers. Thus, the job reallocation concept in this paper differs from, but is

${ }^{6}$ Two caveats should be borne in mind when interpreting this aspect of the size-weighted density. First, our size metric $\left(x_{e t}\right)$ assigns only half as much weight to observations on births and deaths as would a more conventional size metric. For example, if we were to ask what fraction of current employment is located at establishments born within the past year, the birth category would appear twice as important as in Figure 1.B. Second, although births and deaths account for a small fraction of size-weighted establishment growth rate observations, they account for a large fraction of gross job reallocation. We return to this point in section III.C.

${ }^{7}$ Sample weights are suppressed in these formulas to reduce notational clutter. 
related to, the worker turnover concepts considered by Lilien (1980), Hall (1982), Akerlof, Rose and Yellen (1988), and others. We spell out the contribution of job reallocation to worker reallocation in section III.C.

Second, since we observe only plant-level employment, we cannot determine whether a given level of employment in two different periods for the same plant represents the same or different employment positions. This observation and the point-in-time nature of the employment data imply that $P O S_{9 t}$ and $N E G_{\text {at }}$ represent lower bounds on true job creation and destruction rates.

We use the sum of $P O S_{s t}$ and $N E G_{s t}, S U M_{s t}$, to measure the gross job reallocation rate in sector $s$ between $t-1$ and $t$. $X_{s t} S U M_{s t}$ equals the gross change from $t-1$ to $t$ in the number of employment positions at establishments. In terms of the frequency distribution, the job reallocation rate $S U M_{s t}$ can be thought of as the size-weighted mean of the absolute value of establishment growth rates.

To relate job reallocation to worker reallocation, observe that $X_{\text {st }} S U M_{s t}$ represents an upper bound on the number of workers who change jobs or switch between employment and nonemployment in response to establishment-level employment changes. ${ }^{8} X_{s t} S U M_{s s}$ represents an upper bound because some workers move from shrinking to growing establishments within sector $s$ between $t-1$ and $t$. To obtain a lower bound, we eliminate the possibility of double counting job losers who move directly to new jobs at expanding establishments in the same sector. That is, $X_{s t} M A X_{s t}=X_{s t} \operatorname{Max}\left\{P O S_{s t}, N E G_{s t}\right\}$ represents a lower bound on the number of workers who change jobs or employment status in direct response to job reallocation in sector $s$. In line with this discussion, we often refer to $S U M_{s t}$ and $M A_{1} Y_{s t}$ as upper and lower bounds on the worker reallocation rate required to accommodate job reallocation. When interpreting these upper and lower bounds, it is important to recognize that the worker reallocation associated with job reallocation is itself a lower bound on total worker reallocation. Worker reallocation arises in response to life-cycle, career path, job satisfaction, and match quality considerations as well as in response to job reallocation.

\section{Some Elementary Facts about Job Creation and Destruction ,}

This section of the paper lays out some elementary facts about job creation and destruction behavior in the U.S. manufacturing sector. We relate these facts to the magnitude and character' of the worker reallocation associated with job reallocation. These facts also set the stage for the analysis in the succeeding sections of the paper.

${ }^{8}$ The interpretation of $X_{a t} S U M_{a t}$ as an upper bound is subject to the qualifications about the lower-bound nature of POS, and NEG.t discussed above. 


\section{A. Magnitude and Time Variation}

Table 1 presents annual rates of job creation and destruction, net employment growth, job reallocation, and a lower bound on the worker reallocation required to accommodate job reallocation. The figures in Table 1 and elsewhere in this paper are based on Marchto-March changes in establishment-level employment.

The central fact captured by Table 1 is the phenomenon of simultaneous job creation and destruction. Every year of the sample exhibits both job creation and job destruction rates that exceed six percent of manufacturing employment. In 1973, when manufacturing employment expanded by a robust seven percent on net, the gross job destruction rate was six percent. In 1975, when manufacturing employment shrank by a dramatic ten percent, the gross job creation rate was seven percent.

The last two columns in Table 1 point out the tremendous reallocation of jobs and workers associated with simultaneous job creation and destruction. The job reallocation rate ranges from $17.3 \%$ in 1980 to $23.3 \%$ in 1975 . Substantial worker reallocation is required to accommodate job reallocation of this magnitude. The lower bound on the required rate of worker reallocation ranges from $10.2 \%$ of employment in 1980 to $16.6 \%$ in 1975. Thus, the heterogeneity of establishment-level employment movements illustrated in Figures 1 translates into an impressive amount of worker reallocation.

One other noteworthy fact emerges from Table 1: The pace of job reallocation exhibits significant countercyclic time variation. The range of variation in job reallocation over the eleven years of the sample is six percentage points. The simple correlation between the net job growth rate and the job reallocation rate equals -.57 . Given the magnitude of job reallocation, its significant time variation, and the countercyclic pattern of the time variation, one is led naturally to inquire about the connection between the pace of job reallocation and aggregate employment fluctuations. We take up this inquiry in section $\mathrm{V}$.

\section{B. Cross-Industry Variation}

Table 2 presents average annual net and gross job flow measures for the manufacturing sector and each two-digit industry. The industry figures are $X_{i t}$-weighted averages of the eleven annual industry observations, and the figures for the manufacturing sector are $X_{i-}$ weighted averages of the industry figures.

Employment contracted in every two-digit manufacturing industry over the sample. Annual net contraction rates range from $.2 \%$ in Instruments to $5.4 \%$ in Primary Metals. The manufacturing sector as a whole declined at a rate of $2.1 \%$ per year. Despite pervasive net contractions, every two-digit industry experienced significant gross job creation. Average March-to-March gross job creation rates range from $5.8 \%$ in Tobacco to $12.9 \%$ 
in Lumber and Wood Products. March-to-March gross job destruction rates range from $7.8 \%$ in Paper to $16.0 \%$ in Lumber and Wood Products. In the manufacturing sector as a whole, gross job creation and destruction rates averaged $9.2 \%$ and $11.3 \%$, respectively.

The annual average job reallocation rate shows considerable cross-industry variation, ranging from $14.0 \%$ in Tobacco to $28.8 \%$ in Lumber and Wood Products. The lower bound on the rate of worker reallocation required to accommodate observed job reallocation ranges from $8.9 \%$ in Chemicals and Paper to $18.8 \%$ in Lumber and Wood Products. For the manufacturing sector as a whole, the lower (upper) bound on the required rate of worker reallocation equals $12.9 \%(20.5 \%)$ of employment per year.

The final column of Table 2 shows that simultaneous job creation and destruction is an important phenomenon in every two-digit manufacturing industry. This column reports average industry rates of excess job reallocation, i.e., the mean difference between total job reallocation and the minimum job reallocation required to accommodate net employment changes. The excess job reallocation rate varies from $9.8 \%$ to $20.6 \%$ across two-digit industries. The size-weighted average of the two-digit industry excess job reallocation rates equals $15.2 \%$ of employment. These striking facts, and their bearing on worker reallocation, provide strong motivation for an inquiry into the underlying sources of the establishmentlevel heterogeneity responsible for simultaneous job creation and destruction. We take up this inquiry in section IV.

\section{The Connection to Total Worker Reallocation}

The preceding results indicate that a substantial fraction of total worker reallocation is demand driven in the sense of being induced by shifts in the distribution of employment opportunities across work sites. To quantify this statement, we now compare the total number of persons who switch jobs or employment status to the number of switches required to accommodate the reallocation of jobs.

Recall that our job reallocation figures are based on employment changes over a twelve-month interval. A meaningful comparison requires a consistent measure of total worker reallocation. With this observation in mind, we calculate total worker reallocation as the sum of two pieces. The first piece is the number of persons who have job tenure of twelve months or less. Based on the Current Population Survey (CPS), Hall (1982, p. 317 ) reports that this number is $28.2 \%$ of employment in 1978 . The second piece is the number of currently jobless persons who were employed twelve months earlier. Summing these two pieces yields the total number of persons who currently have a different job and/or employment status than they had twelve months earlier.

To calculate the second piece of total worker reallocation, we tabulated March-toMarch gross worker flows from the CPS. Gross worker flows refer to the number of persons 
who report a change in labor force status - employed, unemployed; or out of the labor force - between survey dates. Using the March-March matched files of the CPS, we obtained the three-by-three matrix of gross flows, $F$, for fifteen pairs of years between 1968 and 1987. Since reporting errors are known to cause a substantial upward bias in the measured flows, we adjusted the $F$ matrices following Poterba and Summers (1986). Letting $Q$ denote the three-by-three matrix of classification error probabilities, the measured and true gross flows satisfy the relationship $F=Q^{\prime} F^{*} Q$, where $F^{*}$ denotes the true flows. Obtaining $\hat{Q}$ from Table 3 in Poterba and Summers, we estimate the true gross flow matrix in year $t$ as $\hat{F}_{t}=\left(\hat{Q}^{-1}\right)^{\prime} F_{t} \hat{Q}^{-1}$. Collapsing unemployment and out of the labor force into a single category, we then calculate the yearly number of transitions from employment to joblessness as a percentage of employment. Averaging this transition rate over the fifteen years, we estimate that the number of currently jobless persons who held a job twelve months earlier as $8.6 \%$ of employment. (The corresponding figure unadjusted for classification error is $11.2 \%$ of employment.)

Summing the two pieces, total worker reallocation equals $28.2+8.6=36.8$ percent of employment in a typical year. From Table 2, the amount of worker reallocation required to accommodate job reallocation is bounded between $12.9 \%$ and $20.5 \%$ of employment in a typical year. Hence, taking the ratio of the job reallocation figures to the total worker reallocation figure, we calculate that $35-56 \%$ of total worker reallocation arises to accommodate shifts in the distribution of employment opportunities across work sites. Simply put, job reallocation accounts for a major fraction of total worker reallocation. 9

Two observations provide further perspective on the magnitude of job reallocation's contribution to worker reallocation. First, our calculations neglect secondary waves of worker reallocation initiated by job creation and destruction. For example, a person who quits an old job in favor of a newly-created job potentially creates a chain of further quits

${ }^{9}$ Three sources of potential bias in our calculations seem sufficiently important to merit mention. First, Hall's job tenure figure understates worker mobility (for our purposes), because it does not include workers who, within the past twelve months, transferred between plants owned by the same employer. Third, the attrition rate in the March-March matched files of the CPS may be higher for workers who change employment status. Both of these effects bias the denominator of the calculated ratio downward. Third, our job reallocation figures are based on the manufacturing sector only. According to Leonard's (1987, Table 6.6) tabulations for Wisconsin, annual job reallocation rates are $28 \%$ higher in nonmanufacturing than in manufacturing. Thus, Leonard's results suggest that the numerator of our calculated ratio significantly understates the job reallocation rate in the economy as a whole. 
as other workers re-shuffle across the new set of jobs. It follows that the direct plus indirect contribution of job reallocation to total worker reallocation exceeds the figure we derived above.

Second, a certain amount of worker reallocation inevitably arises from life-cycle considerations as old workers retire and young workers enter the workforce. If the typical person works forty-five years, then retirement and initial labor force entry directly cause transitions between employment and nonemployment equal to roughly $4.4 \%$ of the workforce in a typical year. It follows from our figure for total worker reallocation that simple life-cycle effects account for roughly $12 \%$ of total worker reallocation. After accounting for job reallocation and life-cycle effects, the residual amount of worker reallocation equals 11.9-19.5\% of employment, or $33-53 \%$ of total worker reallocation. This component of worker reallocation reflects temporary exits from the workforce and the sorting and resorting of workers across existing jobs for a variety of reasons.

We conclude this discussion with a caveat. Recall that our job and worker reallocation figures are based on changes between two points in time twelve months apart. Carrying out similar calculations for data based on, say, monthly sampling would place greater emphasis on seasonal disturbances and other factors that lead to transitory flows of workers and jobs. To the extent that these factors disproportionately affect worker or job flow rates, a different calculation of job reallocation's contribution to total worker reallocation would emerge.

\section{Concentration and Persistence}

The high rates of job reallocation reported in Tables 1 and 2 prompt two further factual questions. First, what role do plant births and deaths play in the creation and destruction of jobs? Or, to restate the question in a more general way, how are job creation and destruction distributed by establishment growth rate? Second, do the high rates of job creation and destruction reported in Tables 1 and 2 reflect primarily transitory or persistent establishment-level employment changes? We address these questions in turn.

Gross job creation and destruction are distributed over establishments experiencing the full range of expansion and contraction rates. Figure 2 displays the distributions of job creation and destruction over this range. The right half of Figure 2 plots the fraction of job creation accounted for by establishments experiencing growth rates in the intervals $[0, .1),(.1, .2), \ldots[1.9,2.0)$. A final category shows the fraction of job creation accounted for by establishment births. The left half of Figure 2 provides a symmetric partition of gross job destruction. 
Figure 2 highlights two noteworthy aspects of job creation and destruction. First, both large discrete changes and smaller incremental changes account for significant fractions of job creation and destruction. Establishments experiencing modest growth rates $(|g|<.20)$ account for $29 \%$ of job creation and $23 \%$ of job destruction. Establishments experiencing dramatic growth rates $(|g|>1.0)$ account for $28 \%$ of job creation and $34 \%$ of job destruction. Births (deaths) alone account for $20 \%(25 \%)$ of job creation (destruction). ${ }^{10}$

Second, Figure 2 reveals a clear asymmetry between the distributions of job creation and destruction by establishment growth rate. Relative to job creation, job destruction exhibits greater concentration at establishments that experience dramatic growth rates. This aspect of job creation and destruction behavior provides support for theories of plantlevel employment dynamics that generate greater lumpiness in employment contraction than employment expansion.

We now turn to the persistence of the March-to-March establishment-level employment changes that underlie our annual job creation and destruction measures. The persistence question is especially pertinent to an assessment of the character of worker reallocation associated with job reallocation. To the extent that job creation and destruction represent short-lived establishment-level employment changes, these changes can be implemented largely through temporary layoffs and recalls. To the extent that establishmentlevel employment changes are persistent, they must be associated with long-term joblessness and/or worker reallocation across plants.

In thinking about how to measure persistence, we stress that our focus is on the persistence of the typical newly-created or newly-destroyed job. This focus is distinct from a focus on the persistence of the typical existing job (e.g., Dunne and Roberts, 1089) or the persistence of establishment size (e.g., Leonard, 1987). In line with our focus, we measure persistence as follows. Let $F P O S_{11}$ denote the fraction of newly-created jobs in March of year $t$ that continue to be present in March of year $t+1 .^{11}$ Also, let FPOS 12 ${ }^{10} \mathrm{An}$ earlier version of this paper reports partitions of job creation and destruction by year and partitions by two-digit industry. These more detailed results show that the important role of dramatic establishment-level employment changes illustrated in Figure 2 is pervasive across industries and years. For example, the fraction of job destruction accounted for by establishment deaths ranges from $14-36 \%$ across years and 15-35\%, on average, across two-digit industries.

${ }^{\text {"Let }} E M P_{\mathrm{et}}$ denote time-t employment at establishment $e$. Newly-created jobs at $e$ in $t$ equal $E M P_{\mathrm{et}}-E M P_{\mathrm{e}, t-1}$, assuming positive growth. If $E M P_{\mathrm{e}, t+1} \geq E M P_{\mathrm{et}}$, then all of these newly-created jobs are present in $t+1$. If $E M P_{e, 1+1} \leq E M P_{e, 1-1}$, then none of the newly-created jobs are present in $t+1$. If $E M P_{e, t+1} \in\left[E M P_{e, t-1}, E M P_{e t}\right]$, then 
denote the fraction of newly-created jobs in March of year $t$ that are present in March of year $t+1$ and March of year $t+2$. Define $F N E G_{t n}$ analogously.

Table 3 reports the persistence measures for a set of base years determined by the lifecycle of the ASM panels. The key fact captured by the table is the highly persistent nature of the establishment-level employment movements underlying annual job creation and destruction. To take the most pronounced example, the one-year persistence rate for jobs destroyed between March 1980 and March 1981 is $88 \%$, and the two-year persistence rate for these lost jobs is $82 \%$. The average one-year persistence rates for newly-created and newly-destroyed jobs are $68 \%$ and $81 \%$, respectively.

These facts on concentration and persistence shed further light on the connection between job reallocation and worker reallocation. Since only $23 \%$ of job destruction is accounted for by establishments that shrink by less than twenty percent over the span of a year, the bulk of job destruction cannot be accommodated by normal rates of worker attrition. Since annual job creation and destruction primarily reflect persistent establishmentlevel employment changes, the bulk of annual job creation and destruction cannot be implemented by temporary layoff and recall policies.

\section{Explanations for Simultaneous Job Creation and Destruction}

The preceding section established that job reallocation is large in magnitude and that it accounts for a large fraction of total worker reallocation. This section investigates the sources of establishment-level heterogeneity that lead to simultaneous job creation and destruction within industries. We draw on several theories of plant-level heterogeneity and dynamics to identify potential driving forces behind simultaneous job creation and destruction. We then quantify the contribution of various sources of heterogeneity to total job reallocation and to variation in job reallocation across groups of establishments defined in terms of industry and other observable characteristics.

\section{A. Theories of Beterogeneity that Explain Simultaneous Job Creation and Destruction}

One prominent theory of heterogeneity in firm- and plant-level employment dynamics stresses the selection effects associated with passive learning about initial conditions. In this type of theory, plants face ex ante uncertainty about certain cost parameters or their level of efficiency. A plant's underiying efficiency level cannot be directly observed but is learned over time through the process of production. A plant that accurnulates favorable

$E M P_{e, t+1}-E M P_{e, t-1}$ of the newly-created jobs are present in $t+1$. Carrying out this calculation for all growing establishments in $t$ and dividing the result by $P O S_{t}$ yields FPOS $_{11}$. 
information about its efficiency expands and survives, whereas a plant that accumulates sufficiently unfavorable information chooses to exit. Well-articulated theories of this sort include Jovanovic (1982), Lippman and Rumelt (1982), and Pakes and Ericson's (1990) version of the Jovanovic model. Much of the empirical analysis in recent studies of firmlevel and plant-level employment dynamics is explicitly couched in terms of this type of theory - see Evans (1987ab), Hall (1087), Dunne, Roberts and Samuelson (1989a), and Pakes and Ericson (1990).

As a stand-alone theory, passive learning and selection cannot explain perpetual plant turnover within an industry. Eventually, plants learn their underlying efficiency level and decide whether to exit or remain indefinitely. The transitory, idiosyncratic cost disturbances present in the Jovanovic model generate transitory, plant-level employment fluctuations that continue indefinitely, but the existence of sunk costs associated with entry and exit insures that the set of surviving plants eventually becomes fixed in the absence of some other type of disturbance. Hence, we view passive learning and selection as a mechanism that magnifies the job reallocation and plant turnover response to other disturbances. For example, passive learning might explain why an industry that experiences steady growth also exhibits gross job destruction associated with plant deaths.

Another reason for the co-existence of job creation and destruction is technical innovation that leads to the replacement of old, outmoded plants by new, technologically superior plants. Simultaneous job creation and destruction accompanies the technological upgrading and plant turnover process. Bresnahan and Raff (1990) pursue this theme in their analysis of technological heterogeneity in the American auto industry during the 1920's and 1930's. However, Dunne, Roberts and Samuelson (1989b, Table 5) present evidence that the rate of job destruction associated with plant death declines as plants age. This fact is difficult to reconcile with a simple monocausal theory of plant turnover and job reallocation driven by exogenous technical change, but it does not preclude a major role for technical change in a full explanation for job reallocation and plant turnover.

Ericson and Pakes (1989) and Pakes and Ericson (1990) develop a theory of firm and industry dynamics in which investment outcomes involve idiosyncratic uncertainty. The stochastic outcomes of an individual plant's investments, coupled with competitors' investment outcomes, determine the probability distribution over future profitability streams. A plant's investment. outcome may improve its position relative to its competitors, thus leading to expansion, or it may cause a relative deterioration, thus leading to contraction and, possibly, exit. Investment in the Ericson-Pakes model thus involves elements of active learning and selection. Unlike the passive learning and selection model of Jovanovic (1982), the Ericson-Pakes model builds in an explanation for perpetual entry and exit - 
the outside industry or competitors stochastically, but exogenously, advance along an efficiency path. Hence, the active learning theory embeds technical change into a rich model of plant-level heterogeneity and selection.

Another class of theories stresses differences in initial conditions, or uncertainties about future conditions, that lead firms to commit to different factor intensities and production techniques. These differences in turn lead to heterogeneity in plant-level responses to common cost and demand shocks. These sources of heterogeneity, and their connection to the simultaneous entry and exit of plants, are nicely analyzed in Lambson (1990).

Finally, even plants that produce identical products with identical technologies can face idiosyncratic cost disturbances. As examples, energy costs and tax burdens are often heavily influenced by local conditions. Exogenous, idiosyncratic cost disturbances lead to contraction at some plants and, simultaneously, expansion at other plants. In related work, Davis and Haltiwanger (1990), we develop a general equilibrium model of employment reallocation and job turnover driven by exogenous, idiosyncratic cost disturbances.

The preceding remarks identify several theories or factors that plausibly account for simultaneously large job creation and destruction rates within narrowly-defined sectors of the economy. While a full assessment of each theory is beyond the scope of a single paper, we exploit several observable plant characteristics to quantify the contribution of some potentially important factors to job reallocation. In addition to industry, the observable plant characteristics we consider are plant age, size, geographic region, and ownership type. (Ownership type refers to whether a plant is owned by a single-plant firm or a multi-plant firm.) We interpret these plant characteristics as observable correlates of technical change, choice of production technique, differences in initial conditions, locationspecific disturbances, organizational scale, and the progressive resolution of uncertainty about initial conditions.

\section{B. Variation by Region, Size, Age and Ownership Type}

Table 4 displays net and gross job flow rates cross-tabulated by plant size, age, ownership type, and geographic region. The rightmost column reports the distribution of manufacturing employment by plant characteristic. Except for plant age, the figures in Table 4 represent average annual rates over the eleven years in our sample. Since our ability to construct detailed age categories is greatest in the last year of complete panels, we report averages of 1978 and 1983 values for the age figures.

According to Table 4, every region except the Mountain region experienced net job loss over the sample period. The variation in net job loss rates is quite small across plants of different average sizes and ownership types. In contrast, net job loss rates vary greatly by plant age. Young plants grow rapidly on average, while older plants shrink on average. 
The gross job flow measures exhibit strong patterns of variation within each grouping of plants in Table 4. The western geographic regions exhibit noticeably higher job reallocation rates than the rest of the country. Job reallocation rates for single-unit plants are half again as large as reallocation rates for plants operated by multi-unit firms. Job reallocation rates decline sharply with average establishment size, ranging from $14 \%$ at plants with $1000+$ employees to $30 \%$ at plants with 1-99 employees.

The most dramatic variation in gross job flow rates occurs with respect to plant age. For plants that are one-year old in the base year, the annual job reallocation rate averages a remarkable $48 \% .^{12}$ The job reallocation rate drops off rapidly to roughly $26 \%$ by age three, and it declines further to $16 \%$ for plants that are at least fifteen years old. Unreported results reveal that this sharp relationship between plant age and the job reallocation rate is pervasive across two-digit industries, geographic regions, plant size classes, and plant ownership types.

These facts about variation in job reallocation rates by plant characteristic are consistent with the existing literature on heterogeneity in firm dynamics. Our measure of dispersion and our scheme for weighting establishment-level observations differ from previous studies, but sharp declines in employment volatility with plant size and age are robust findings in the literature. In seeking explanations for simultaneous job creation and destruction, the especially sharp and pervasive relationship between job reallocation and plant age impels one toward theories that can also explain this fact. Theories based on passive learning and selection suggest an interpretation of this fact as the natural outcome of a progressive resolution of uncertainty about initial conditions. In the next section, we quantify the extent to which this type of theory can explain the magnitude of job reallocation and the variation in job reallocation rates across industries, regions, plant size classes, and plant ownership types.

\section{Quantifying the Role of Passive Learning about Initial Conditions}

Consider the following counterfactual question: How much would gross job reallocation be diminished if selection effects associated with passive learning about initial conditions were absent from the economic environment determining firm dynamics? We provide an answer to this question by bringing some simple identifying assumptions to bear on the age-related information in Table 4.

${ }^{12}$ This figure is not inflated by including re-openings of previously idled plants. As the LRD enables us to track re-openings of older plants, their contribution to job creation and reallocation is allocated to the appropriate plant age category. 


\section{Identifying Assumptions and Methodology}

If plants accumulate information over time about an unknown, but time-invariant, cost parameter, then the posterior distribution eventually converges in probability to the true value. Assume that this convergence process is largely complete within $n$ years of plant birth. This is our central identifying assumption. It follows from this assumption that none of the job reallocation among mature plants (age $\geq n$ ) reflects selection effects associated with passive learning about initial conditions.

Now, consider how we might exploit this identifying assumption to answer the counterfactual question. Besides the passive learning mechanism, many factors contribute to simultaneous job creation and destruction within industries or sectors of the economy. Except as described below, we assume that these other factors have age-neutral effects on job reallocation rates. This assumption means that these other factors generate the same base job reallocation rate for younger and older plants. Thus, as our second identifying assumption, we take the "base" reallocation rate to be age invariant.

Combining the two identifying assumptions, the fraction of job reallocation caused by passive learning and selection is

$$
P=\frac{\sum_{a<n} x(a)[r(a)-r(\text { age } \geq n)]}{r X}=\left[\sum_{a<n} \frac{x(a)}{X}[r(a)-r(\text { age } \geq n)]\right] / r
$$

where $x(a) / X$ is the ath age group's share of sectoral employment, $r(a)$ is the measured job reallocation rate of age group $a$, and $r$ denotes the sectoral job reallocation rate. The term $r($ age $\geq n)$, equal to the measured job reallocation rate among mature plants, represents the base rate of job reallocation that is assumed to be age invariant. Thus, the formula counts all job reallocation in excess of the base amount as arising from passive learning effects.

Besides passive learning, other factors may lead to age-nonneutral effects on the job reallocation rate. For example, consider the following characterization of an industry equilibrium like the one articulated by Jovanovic. Suppose that industry demand and employment grow at a constant rate through time. Job reallocation among mature plants arises because of the transitory, idiosyncratic cost (or demand) disturbances present in the Jovanovic model. Among younger plants, however, job reallocation also arises because of selection effects associated with passive learning about initial plant conditions. Thus, along the stationary growth path for the industry, new plants continuously enter to accommodate net industry expansion and to replace dying plants. Because of the ongoing selection process associated with passive learning, gross job destruction exceeds zero, and 
gross job creation exceeds net job creation by an equal amount. Since job reallocation among mature plants reflects transitory and idiosyncratic disturbances, there is no reason to expect sharply different job reallocation rates among younger plants in response to these disturbances. However, given diminishing returns at the plant level, net long-run industry growth will occur entirely through the entry of new plants rather than through higher job creation rates among existing plants. Thus, long-run net growth generates agenonneutral effects on job reallocation rates. For this particular case, the adjustment of (1) is straightforward and given by

$$
P=\left[\sum_{a<n} \frac{x(a)}{X}[r(a)-r(\text { age } \geq n)]-g\right] / r
$$

where $g$ denotes the net industry employment growth rate. This alternative formula counts all job reallocation in excess of the base amount and the amount required to accommodate net industry expansion as arising from passive learning effects.

The appropriate adjustment is less clear for a contracting industry, because industry contraction is likely to occur through shrinkage (and death) among plants of various ages. Taking these considerations into account, we modify our second identifying assumption by assuming that (a) net industry contraction has age-neutral effects on the reallocation rates, and (b) net industry expansion has the age-nonneutral effects described above. In line with this modification, the empirical results below estimate the fraction of job reallocation due to passive learning and selection as

$$
P=\left[\sum_{a<n} \frac{x(a)}{X}[r(a)-r(\text { age } \geq n)]-\max \{g, 0\}\right] / r .
$$

Two additional remarks regarding the use of (3) to estimate passive learning's contribution to job reallocation are in order. First, it is conceivable that factors other than net industry growth lead to age-nonneutral effects on the job reallocation rate. These factors potentially bias our estimate of passive learning's contribution to total job reallocation. ${ }^{13}$ To the extent that these age-nonneutral factors reflect transitory or industry-specific disturbances, their impact on the calculation of $P$ for the entire manufacturing sector will ${ }^{13}$ Age-nonneutral disturbances to employment growth rates, as opposed to reallocation rates, do not bias the estimate of passive learning's contribution. For example, a technological innovation that causes an equal rise in gross job destruction among mature plants and in gross job creation among young plants has offsetting effects on the calculation of $P$ in (1)-(3). 
be negligible. To the extent that some unspecified factor systematically causes higher job reallocation rates among young plants, our estimate of passive learning's contribution will be upwardly biased.

Second, sunk costs associated with plant entry imply that transitory fluctuations in industry demand will be largely accommodated by the expansion and contraction of existing firms. The industry response to these disturbances is unlikely to involve a sharply age-nonneutral response in job reallocation rates. Hence, we interpret $g$ in equations (2) and (3) as the long-run net growth rate. Empirically, we estimate $g$ as the average annual employment growth rate in our sample for the industry or sector.

\section{Empirical Results}

We implement equation (3) using pooled sample data from 1978 and 1983, the only years for which we can tabulate the $r(a)$ function by the detailed age categories in Table 4. Carrying out the calculations for $n=4$ years. we find that selection effects associated with learning about initial conditions account for $11 \%$ of total job reallocation in the U.S. manufacturing sector. Repeating the calculations under the assumption that plants completely learn their underlying efficiency level by age six, learning about initial conditions explains $13 \%$ of job reallocation in the manufacturing sector. The key finding contained in these results is that learning about initial conditions explains only a small fraction of total job reallocation.

This finding is unlikely to be overturned by reasonable modifications of our procedure or identifying assumptions. Table 4 indicates why: nearly nine-tenths of manufacturing employment is located at plants more than six years old, yet these plants exhibit substantial job reallocation rates. Learning about initial conditions is not a plausible explanation for high job reallocation rates among these plants.

The small contribution of learning to total job reallocation does not preclude a large role for learning in the cross-sectoral variation in job reallocation rates (Tables 2 and 4). For example, selection effects associated with learning about initial conditions might play a more important role among small establishments than among large establishments. Selection effects associated with uncertain imitability à la Lippman and Rumelt (1082) are likely to be more important for single-plant than multi-plant firms, because technology transference between plants within a firm is relatively easy. Other things equal, selection effects associated with learning about initial conditions will be more important in rapidly growing sectors than in mature or contracting sectors.

To investigate cross-sectoral differences in the importance of learning about initial conditions, we implemented equation (3) for each two-digit industry, geographic region, size class, and plant ownership type. Table 5 reports selected results. The results show 
considerable cross-sectoral variation in the fraction of job reallocation explained by learning about initial conditions, although learning never explains more than one-fifth of sectoral job reallocation. Learning about initial conditions is relatively important in the western states, among small plants, and among plants owned by a single-unit firm. As indicated in Tables 2 and 4, these sectors also display high total rates of job reallocation. Thus, the detailed resuits in Table 5 suggest that cross-sectoral differences in learning about initial conditions account for much of the observed cross-sectoral differences in job reallocation rates.

Table 6 quantifies the ability of the passive learning story to explain cross-sectoral differences in job reallocation rates. The first row of the table reports the cross-sectoral standard deviation of job reallocation rates for alternative sectoral classification schemes. The next two rows present estimates of the fraction of the cross-sectoral variance in job reallocation rates explained by the passive learning story. In computing these estimates, we rely on equation (3) to compute sectoral job reallocation rates net of the estimated contribution of learning about initial conditions.

The Table 6 results indicate that differences in the importance of learning about initial conditions explain a major portion of observed cross-sectoral differences in job reallocation rates. Learning about initial conditions explains one-third or more of the variation in job reallocation rates among two-digit industries and census geographic reasons. Learning explains over half of the variation in job reallocation rates among plants of differing sizes and between single-unit and multi-unit plants.

In terms of explaining job reallocation behavior, we can summarize the empirical performance of the passive learning story as follows. Learning about initial conditions provides a plausible explanation for the sharp and pervasive relationship between job reallocation rates and plant age. This aspect of our results confirms closely-related findings by Evans (1987ab), Hall (1987) and Dunne, Roberts and Samuelson (1989a). In addition, Table 6 indicates that the passive learning story also explains much of the cross-sectoral variation in job reallocation intensity. These results lead us to conclude that the passive learning story is quite useful for interpreting variation in job reallocation intensity across different types of plants.

On the more fundamental matter of explaining the overall magnitude of job reallocation, the passive learning story is far less successful. Learning about initial conditions accounts for a small portion, 11-13\%, of total job reallocation and only a slightly larger fraction of excess job reallocation. This result prompts us to investigate another potential explanation for high rates of excess job reallocation. 


\section{Quantifying the Role of Between-Sector Employment Shifts}

Disturbances that cause a reshuffling of employment between different sectors or groups of plants generate simultaneous job creation and destruction. This simple point immediately raises two questions: What fraction of excess job reallocation can be explained by the reshuffling of employment between groups of plants defined in terms of interesting observable characteristics? And, which observable plant characteristics are most useful in accounting for excess job reallocation? As before, we define excess job reallocation as total job reallocation minus the minimum level required to accommodate net employment expansion or contraction.

We address these questions by decomposing excess job reallocation for the manufacturing sector, and for each two-digit industry, into two components. ${ }^{14}$ One component represents the contribution of reshuffling employment between sectors, and the other component represents the contribution of excess job reallocation within sectors. Summing the two components yields overall excess job reallocation. The component of excess job reallocation due to between-sector employment shifts is given by

$$
\sum_{s=1}^{s} \mid \text { Net Employment Change in } s|-| \text { Overall Net Employment Change|, }
$$

where $s$ indexes sectors. The component due to excess job reallocation within sectors is given by

$$
\left.\sum_{s=1}^{S} \text { (Job Reallocation in } s-\mid \text { Net Employment Change in } s \mid\right) \text {. }
$$

Table 7 reports the results of decomposing excess job reallocation for sectoral classification schemes defined in terms of plant age, size, region, ownership type, and industry. Our earlier discussion identified these variables as observable correlates of the factors that underlie heterogeneity in plant-level employment dynamics. Each entry in Table 7 reports the fraction of excess job reallocation explained by between-sector employment shifts for the indicated sectoral classification.

The most remarkable aspect of Table $T$ is the inability of between-sector employment shifts to account for excess job reallocation. According to the top panel, employment shifts among plants of different ages, sizes, regions, ownership types, and two-digit industries account for virtually none of the excess job reallocation in the manufacturing sector as a

${ }^{14}$ Dunne, Roberts and Samuelson (1989b) exploit an equivalent decomposition in their analysis of gross job flows over five-year intervals. 
whole. Cutting sectors much more finely by defining them in terms of age, size, region, and ownership simultaneously, between-sector employment shifts account for only $15 \%$ of excess job reallocation. Employment shifts among the 450 four-digit manufacturing industries account for a mere $12 \%$ of excess job reallocation. Even when we define sectors in terms of all five plant characteristics simultaneously, between-sector employment shifts account for only $39 \%$ of excess job reallocation. To appreciate the level of detail captured by this classification scheme, we remark that the average nonempty "sector" contains only about tive sampled plants.

The industry-level decompositions in Table 7 carry the same basic message, although some additional patterns emerge. Most notably, for every two-digit industry the age-based sectoral classification scheme yields a more successful accounting of excess job reallocation than any other classification scheme based on a single plant characteristic. Employment shifts between age groups account for one-tenth or more of excess job reallocation in most industries and roughly one-fifth of excess job reallocation in a handful of industries. The age results suggest that theories stressing embodied technical change or other sources of vintage effects are likely to provide a partial explanation for high rates of excess job reallocation.

The results in Table 7 argue strongly against the view that high rates of excess job reallocation arise primarily because of sectoral disturbances or economywide disturbances with differential sectoral effects. Instead, Table $T$ argues that excess job reallocation is fundamentally a phenomenon related to plant-level heterogeneity in labor demand behavior. Learning about initial conditions is one reason for plant-level heterogeneity in labor demand, but we found that this story has limited ability to explain the magnitude of job reallocation. Theories that stress active learning and selection among young and old plants (Ericson and Pakes, 1989), theories that stress endogenous precommitment to heterogenous production technologies (Lambson, 1990), and theories that stress exogenous plant-specific cost or demand disturbances (Davis and Haltiwanger, 1090) all seem consistent with the results in Table $i$. Further investigation into the ability of these theories to explain high rates of excess job reallocation must await future research.

\section{Accounting for Time Variation in Job Reallocation Intensity}

Table 1 showed that the pace of job reallocation exhibits significant countercyclic variation in our sample. For example, between the business cycle trough in 1975 and the peak in 1980 the job reallocation rate fell by six percentage points. This cyclical pattern is confirmed in subsequent research that relies on data for other time periods, sectors, and countries. Blanchard and Diamond (1990) demonstrate a close relationship 
between our job creation and destruction figures and appropriately adjusted measures of job turnover in the BLS manufacturing turnover series. They find that their related job reallocation measure fluctuates countercyclically over the 1958 to 1981 period. Based on BLS establishment-level data, Bronars (1990) finds significant countercylical variation in the job reallocation rate for every one-digit industry group in the U.S. over the 1972 1989 period. Tabulations in Baldwin and Gorecki (1990, Table 3.5) reveal countercyclic job reallocation behavior in the Canadian manufacturing sector during the 1970 to 1981 period. Regev (1990) reports countercyclical variation in job reallocation rates for Israel during the 1980's.

These empirical results point to a close relationship between the business cycle and the intensity of job reallocation, but they do not address the question of why the job reallocation rate fluctuates countercyclically. In view of the links between job reallocation and worker reallocation, an answer to this question will provide insight into the source and nature of aggregate labor market fluctuations. To address the question of why job reallocation moves countercyclically, we first address two simpler questions: How much of the time variation in job reallocation is accounted for by mean translations of the establishment-level growth rate density and differential mean sectoral responses to aggregate disturbances? And, how does the cyclical behavior of job reallocation differ by industry type, plant size, age and ownership type? Drawing on our answers to these questions, we then discriminate between macroeconomic theories that cannot explain the observed cyclical behavior of job reallocation and theories that potentially can.

\section{A. An Accounting Framework}

Consider the linear model for establishment-level employment growth rates

$$
g_{e t}=\bar{g}_{e t}^{S T}+g_{s t}+g_{t},
$$

where $g_{t}$ is the manufacturing growth rate, $g_{s t}$ is the sector growth rate (deviated about the manufacturing growth rate), and $\bar{g}_{e t}^{S T}$ is the residual idiosyncratic component of the establishment growth rate. According to equation (4), each establishment's growth rate at $t$ is the sum of an aggregate-time effect, a sector-time effect and a time-varying idiosyncratic effect. Time variation in the realized aggregate and sectoral growth rates induce time variation in the location and shape of the density over the (size-weighted) $g_{e t}$, thereby generating time variation in gross job creation, destruction and reallocation. The crosssectional variance and higher moments of the idiosyncratic component, $\dot{g}_{e t}^{S T}$, also influence the shape of the growth rate density, thereby generating further time variation in the job flow measures. 
Several alternative views about the nature of aggregate fluctuations can be couched in terms of equations like (4). Prevailing views of the business cycle stress the role of aggregate disturbances as driving forces. The simplest version of this view implies that all time variation in gross job creation, destruction and reallocation reflects by time variation in the aggregate-time effects. This view encompasses a time-invariant, but possibly large, cross-sectional variance of the idiosyncratic component of the $g_{e t}$. We represent this pure aggregate shifts story by the hypothesis that the distribution over the $\bar{g}_{\mathrm{et}}^{T}=g_{\mathrm{ct}}-g_{\mathrm{t}}$ is time invariant.

A less simplistic characterization of prevailing views about the business cycle would incorporate differences in the timing and magnitude of sectoral responses to aggregate disturbances. Systematic cross-sectoral differences in the responses to aggregate disturbances are an important element of traditional views about the business cycle. See Abraham and Katz (1986) on this point.

To capture this aspect of traditional views, we allow for completely unrestricted sectoral responses to aggregate disturbances. In particular, consider the hypothesis of a time-invariant distribution over the $\tilde{g}_{\mathrm{el}}^{S T}$. In view of (4), the sector-time effects $g_{\text {at }}$ capture any systematic or non-systematic cross-sectoral differences in the mean response to aggregate disturbances. Neither linearity, magnitude, nor timing restrictions are placed on the mean sectoral responses to aggregate disturbances under this interpretation of the $g_{a l}$. The only restrictions placed on mean sectoral responses are those inherent in the sectoral classification scheme itself.

Based on the decomposition in (4), we measure the relative importance of aggregate, sectoral and idiosyncratic components for time variation in job creation, destruction and reallocation. We also measure the covariation between the components. To see our procedure, consider the distribution over the $\tilde{g}_{e t}^{S T}$, from which we compute job creation, destruction and reallocation rates adjusted for the aggregate-time and the sector-time effects:

$$
\begin{gathered}
\widetilde{P O S_{t}}{ }^{S T}=\sum_{e, g_{e t}>0} \frac{x_{e t}}{X_{t}}\left(\tilde{g}_{e t}^{S T}\right), \\
{\widetilde{N E G_{t}}}^{S T}=\sum_{e, g_{e t}<0} \frac{x_{e t}}{X_{t}}\left(\left|\bar{g}_{e t}^{S T}\right|\right), \quad \text { and } \\
\widetilde{S U M} M_{t}^{S T}=\sum_{e} \frac{x_{e t}}{X_{t}}\left|\bar{g}_{e t}^{S T}\right| .
\end{gathered}
$$

Time variation in these adjusted measures reflects only the contributions of the idiosyncratic effects. Thus, $\widetilde{S U M} l_{1}^{S T}$ measures the gross rate of change in the number of 
establishment-level employment positions as a result of idiosyncratic establishment-level employment movements. From a statistical perspective, $\widetilde{S U M}{ }_{t}^{S T}$ equals the size-weighted average absolute deviation of establishment growth rates around the overall and sectoral means.

Now consider the identity

$$
S U M_{\ell}=\widetilde{S U M} I_{t}^{S T}+\left(S U M_{\ell}-\widetilde{S U M_{t}}\right)^{S T}
$$

which implies the variance decomposition for gross job reallocation,

$$
\operatorname{Var}\left(S U M_{t}\right)=\operatorname{Var}\left(\widetilde{S U M_{t}^{S T}}\right)+\operatorname{Var}\left(S U \cdot M_{t}-\widetilde{S U M}_{t}^{S T}\right)+2 \operatorname{Cov}\left(\widetilde{S U M}_{t}^{S T}, S U M_{t}-S \widetilde{S M} t\right)
$$

If the distribution over the $\bar{g}_{e t}^{S T}$ is time-invariant, then the ratio of $\operatorname{Var}\left(\overline{S U M}_{t}^{S T}\right)$ to $\operatorname{Var}\left(S U M_{t}\right)$ equals zero. Conversely, a large value for this ratio indicates that time variation in the cross-sectional variance (and higher moments) of $\bar{g}_{\mathrm{el}}^{S T}$ accounts for much of the time variation in gross job reallocation. We interpret the covariance term as reflecting the part of time variation in gross job reallocation that cannot be unambiguously assigned to either the aggregate and sectoral effects or to the idiosyncratic effects.

We also decompose the variance of job creation and destruction rates along the lines of (8) and (9). Variance ratios provide information on the relative contribution of aggregate/sectoral versus idiosyncratic effects to time variation in job creation and destruction. The covariance terms indicate whether the idiosyncratic effects reinforce or counteract the impact of aggregate and sectoral effects on job creation and destruction rates.

\section{B. Results}

Table 8 decomposes the time-series variance of annual job reallocation, creation and destruction rates using several sectoral classification schemes. According to the first row of the first panel, aggregate and sectoral effects account for $4.2-10.5 \%$ of the time variation in job reallocation, depending on the classification scheme. Assigning all of the covariance term to the aggregate and sectoral effects, they still account for no more than $20 \%$ percent of time variation in annual job reallocation rates. These results show that time variation in the structure of mean employment growth rates across regions, detailed industries, plant size classes, age groups, and ownership types account for remarkably little of the time variation in job reallocation. The flip side of the same coin is that idiosyncratic effects account for $80 \%$ or more of the variability in annual job reallocation rates. 
Thus, Table 8 finds that only $4-20 \%$ of the time variation in job reallocation rates can be accounted for by mean translations of the growth rate density and differential mean sectoral responses to aggregate disturbances. This finding refutes the hypothesis that some systematic pattern of sectoral responses to aggregate disturbances can account for the significant time variation in gross job reallocation displayed in Table 1. Instead, the time variation in gross job reallocation results overwhelmingly from time variation in the magnitude of idiosyncratic effects. This result is especially striking in that our narrow definition of idiosyncratic effects imposes neither linearity, magnitude nor timing restrictions on the mean sectoral responses to aggregate disturbances.

The second and third panels of Table 8 shed further light on the time-series behavior of gross job reallocation. These panels indicate that aggregate-year effects play a dominant role in accounting for time variation in job creation and destruction rates. The variance of the idiosyncratic component of job creation amounts to only $12-16 \%$ of the overall variance of job creation, and the variance of the idiosyncratic component of job destruction amounts to only $6-8 \%$ of the overall variance of job destruction. The covariance results for job creation and destruction link their behavior to the behavior of job reallocation. For job destruction, the positive sign and large magnitude of the covariance terms indicate that idiosyncratic effects strongly reinforce the countercyclic movements in gross job destruction associated with aggregate mean effects. For job creation, in contrast, the negative sign and large magnitude of the covariance terms indicate that idiosyncratic effects strongly counteract the procyclic fluctuations in job creation associated with aggregate mean effects. Taken together, the covariance terms from the POS and NEG decompositions explain how the idiosyncratic component dominates fluctuations in job reallocation. While $P O S$ falls and $N E G$ rises during economic contractions, idiosyncratic effects counteract the fall in gross job creation while reinforcing the rise in gross job destruction.

We turn now to a more detailed accounting for time variation in job reallocation intensity. Table 9 provides information on the cyclical behavior of sectoral job reallocation rates. The top panel of the table captures two points. First, whether we define sectors in terms of industry, region, size, age or ownership type, movements in both raw and adjusted sectoral job reallocation rates are predominantly countercyclical. For example, all twenty of the two-digit manufacturing industries show countercyclic movements in raw and adjusted job reallocation rates. Second, under each sectoral classification scheme the adjusted job reallocation rate shows a stronger, and typically more pervasive, pattern of countercyclical movements than the raw rate. Focusing on the two-digit industry breakdown again, the mean correlation between the net industry job growth rate and the raw own-industry job reallocation rate equals -.51. Adjusting the empirical growth rate density for aggregate and sectoral effects, and computing the adjusted job reallocation rates, yields 
a mean correlation of -.55 . Thus, rather than providing an explanation for countercyclical fluctuations in job reallocation, sectoral differences in mean growth rates actually mitigate the countercyclicality of job reallocation.

The bottom panel of Table 9 shows how the cyclical behavior of job reallocation varies across sectors. Countercyclic movements in job reallocation rates are more pronounced for larger plants, older plants, multi-unit plants, and plants that produce durable goods.

The results by plant age and size are especially striking. Segregating plants into groups of young (0-9 years) and old (10+ years), and then interacting with two-digit industry, yields forty industry-by-age sectors. For the twenty sectors representing older plants, the size-weighted average correlation between rates of net sectoral growth and adjusted gross job reallocation equals -.71. In sharp contrast, the younger plant sectors show no systematic relation between net job growth and gross job reallocation. These results reveal that the countercyclicality of job reallocation rates entirely reflects greater heterogeneity in the establishment-level employment movements of mature plants during contractions. A similar characterization of cyclical movements in job reallocation rates holds in terms of small versus large plants. Cross-classifying on two-digit industry and our five size classes yields 100 industry-by-size sectors. The average correlation between net sectoral growth and adjusted job reallocation for the forty large plant sectors is - 63 . In contrast, the average correlation for the forty small plant sectors is only - .20 .

It is helpful to place the results in the bottom panel of Table 9 alongside the variance decomposition results in Table $S$. The variance decomposition results show that the great bulk of time variation in gross job reallocation cannot be accounted for by sectoral differences in mean responses to cyclical impulses. The bottom panel of Table 9 indicates that the bulk of time variation in job reallocation can be accounted for by especially sharp countercyclical job reallocation movements among sectors made up of older, larger and multi-unit plants.

While the results in Table 9 provide insight into the basic pattern of time variation in sectoral job reallocation rates, they provide little information about the magnitude of the covariances between net overall and sectoral growth rates, on the one hand, and sectoral job reallocation rates, on the other hand. To investigate the covariance structure, we regress the adjusted sectoral reallocation rates defined by $(\boldsymbol{T})$ on net sectoral and manufacturing growth rates plus interactions of these net rates with age. size and ownership dummies. The regressions also contain sectoral fixed effects to control for permanent sectoral differences in the intensity of job reallocation.

Table 10 summarizes the regressions and reports key results. Column (1) of the top panel, for example, regresses adjusted industry-level job reallocation rates on industry fixed effects and two time-varying covariates: $g_{t}$ and $g_{t t}$. These covariates are highly 
significant ( $t$-statistics greater than five in absolute value), and they account for $27 \%$ of the time variation in industry job reallocation rates. The bottom panel summarizes the implications for the covariance structure. Here, we use the regression to estimate the response of adjusted job reallocation rates to one standard deviation increases in $g_{t}$ and $g_{s t}$. Based on regression (1), for example, a one standard deviation decline in the manufacturing (own-industry) net growth rate is associated with an increase in sectoral job reallocation rates of $1.15(.24)$ percentage points. Relative to regression (1), regressions (2)-(4) add the age, size, and ownership interaction terms, respectively.

Two main results stand out in Table $10 .{ }^{15}$ First, large movements in sectoral job reallocation rates are associated with movements in total manufacturing employment growth rather than movements in own-sector employment growth. This result occurs primarily because the average time-series standard deviation of $g_{s t}$ is small relative to the standard deviation of $g_{t}$. The regression coefficients on $g_{t}$ and $g_{s t}$ differ significantly only for old plants in regression (2).

Second, the covariation between the manufacturing employment growth rate and sectoral job reallocation rates is much larger among old plants than among young plants, among medium-sized and big plants than among small plants, and among multi-unit plants than among single-unit plants. Indeed, there is no evidence of statistically significant covariation between manufacturing or own-sector net employment growth and rates of job reallocation among younger, smaller, and single-unit plants. There is clear evidence of large and highly significant covariation between manufacturing employment growth and rates of job reallocation among older, larger and multi-unit plants.

A similar, but less pronounced, pattern emerges with respect to the covariation between own-sector employment growth and sectoral job reallocation rates. Point estimates indicate greater negative covariation between own-sector employment growth and job reallocation rates among older. larger and multi-unit plants. These differences are statistically significant at the five percent level except for the comparison between multi-unit and single-unit plants. The negative covariation between own-sector employment growth and job reallocation rates is highly statistically significant for old and large plants.

\section{Interpretation of Cyclical Findings}

We have established the following cyclical facts: (1) Job reallocation rates fluctuate countercyclically; this pattern is pervasive across industries and regions. (2) The countercyclic behavior of job reallocation reflects time variation in the magnitude of idiosyncratic

\footnotetext{
${ }^{15}$ The main results in Table 10 are unaffected if we use the raw job reallocation rates as dependent variables in the regressions.
} 
plant-level employment movements, not sectoral differences in the mean employment responses to aggregate disturbances. (3) Job reallocation rates among young (0-9 years), small (1-249 employees), and single-unit plants exhibit little or no systematic relationship to the cycle. (4) Job reallocation rates among older, larger and multi-unit plants exhibit pronounced countercyclic patterns of variation.

What classes of macroeconomic models can explain these facts? It is useful, and perhaps easier, to first identify important classes of models that cannot explain these facts: (i) Models that specify or treat all firms as homogenous. (ii) Sectoral models of the business cycle that specify homogenous firms within sectors. Examples include simple versions of the model described by Lilien (1982), in which sectoral disturbances drive aggregate fluctuations, and the model described by Abraham and Katz (1986), in which aggregate disturbances drive differential sectoral responses. (iii) Sectoral or aggregate models that treat the idiosyncratic component of firm-level employment behavior as orthogonal to the business cycle. This class includes models that specify a cyclically invariant natural rate of unemployment as in Phelps et al (1970). Hall (1979), and Johnson and Layard (1986).

We stress that appending idiosyncratic establishment-level shocks to simple sectoral or aggregate models is not sufficient to explain our cyclical findings. Idiosyncratic establishment-level shocks clearly generate an underlying rate of gross job reallocation within sectors, but they do not necessarily generate a relationship between aggregate fluctuations and the pace of job reallocation. This point is nicely made by Caballero (1990). He posits an asymmetry in firm-level hiring and firing costs in a model that accommodates aggregate and idiosyncratic labor demand disturbances. His adjustment cost specification implies a higher time-series variance in job destruction rates than in job creation rates at the firm level. This feature of the microeconomic structure in Caballero's model is consistent with the pattern displayed in our Figure 2. If this firm-level result carried over to the aggregate level, it would provide an explanation for countercyclic variation in job reallocation rates. ${ }^{16}$ However, Caballero shows that the asymmetry in firm-level job creation and destruction behavior is smoothed away by aggregation when firms exhibit idiosyncratic components to their employment movements. Empirically, we have seen that the idiosyncratic components are large and pervasive.

To explain our findings requires a macroeconomic model that generates simultaneous job creation and destruction within narrowly defined sectors and countercyclical rates of job reallocation within sectors. Progress along these lines is made in recent work by Blanchard and Diamond (1989, 1990), Davis and Haltiwanger (1990), and Caballero (1990).

${ }^{18}$ The raw job reallocation rate, $S U M_{1}$, is negatively correlated with $N E T_{l}$ if, and only if, $\operatorname{Var}\left(N E G_{\imath}\right)$ exceeds $\operatorname{Var}\left(P O S_{t}\right)$. 
These authors specify alternative models that allow both common aggregate and idiosyncratic allocative shocks to influence establishment-level employment dynamics. The models differ in the frictions that they ascribe to the process of reallocating workers and jobs across establishments, but in each model labor market frictions imply potentially important interactions between aggregate employment growth and the pace of reallocation.

These models identify four types of potentially important interactions between the pace of job reallocation and the stage of the business cycle. First, time-series fluctuations in the intensity of allocative shocks can cause aggregate employment fluctuations, as well as countercyclic movements in the job reallocation rate. Second, aggregate shocks can influence the timing of the job reallocation that ultimately arises from allocative shocks, and thereby lead to a bunching of job reallocation activity during downturns. ${ }^{17}$ Third, aggregate downturns may induce a shake-out of less efficient firms and establishments, leading to both aggregate contraction and increased heterogeneity in plant-level employment movements. Fourth, if negative aggregate shocks are more severe (and less frequent) than positive aggregate shocks, then the endogenous evolution of the cross section distribution over plant-level employment growth can generate countercyclic variation in job reallocation intensity.

In light of the findings reported in this paper, disentangling these and other connections between aggregate activity and the pace of job reallocation is an important area for future research. None of the interpretations of countercyclic job reallocation intensity offered by Blanchard-Diamond, Davis-Haltiwanger, and Caballero incorporate an explanation for the findings in this paper related to pronounced differences in the magnitude and cyclicality of job reallocation intensity by plant age, size and ownership type.

\section{Conclusion}

This study paints a sharp picture of gross job flow behavior in U.S. manufacturing industries. Gross rates of job creation and destruction are remarkably large - they amount to roughly ten percent of manufacturing employment in a typical year. The phenomenon of simultaneously high rates of job creation and destruction is pervasive across industries and across groups of plants defined in terms of plant age, size, region and ownership type. In large part, the gross job flows that we measure reflect establishment-level employment changes that are highly persistent and concentrated at plants experjencing sharp expansion or contraction.

${ }^{17}$ Darby, Haltiwanger, and Plant (1985) and Davis (1987) also discuss this reallocation timing effect. 
The magnitude and character of gross job flows bear directly on the reasons for gross worker flows in the labor market. Combining longitudinal information from household and establishment surveys, we calculate that the reallocation of employment opportunities across establishments accounts for $35-56 \%$ of all worker reallocation between employers or between employment and joblessness.

The magnitude and cyclical variability of gross job flows differs systematically across plants with different observable characteristics. On average, job reallocation rates are substantially higher among younger, smaller and single-unit plants. At the same time, job reallocation rates among these plants show no systematic cyclical variation, whereas job reallocation rates among older, larger and multi-unit plants show pronounced countercyclic variation.

This paper provides partial explanations for several aspects of gross job flow behavior. Further research designed to explain gross job flow behavior and to develop its implications for labor market dynamics, for the evolution of firms and industries, and for the nature of business cycles merits a high priority. 
In preparing the data for this study, we have greatly benefited from the assistance of Bob Bechtold, Tim Dunne, Cyr Linonis, Jim Monahan, Al NucCi and other Census Bureau employees at the Center for Economic Studies. We have also greatly benefited from comments on previous drafts by an anonymous referee, Katherine Abraham, Martin Baily, Fischer Black, Tim Dunne, Larry Katz, David Lilien, Robert McGuckin, Kevin M. Murphy, Ariel Pakes, Robert Topel, John Wallis, and workshop participants at the University of Maryland, the University of Chicago, MIT, Princeton University, Stanford University, Yale University, the Federal Reserve Bank of Chicago, the Resource Mobility Session of the Econometric Society (Winter 1988 meetings), an NBER conference on Alternative Explanations of Employment Fluctuations, and the NBER's Economic Fluctuations Program Meeting (Summer 1989). Scott Schuh provided excellent research assistance. Kevin Murphy provided the gross worker flow data from the March-March matched files of the CPS. We gratefully acknowledge the financial assistance of the National Science Foundation (SES-8721031 and SES-8720931), the Hoover Institution, and the office of Graduate Studies and Research at the University of Maryland. Davis also thanks the National science Foundation for its support through a grant to the National Fellows Program at the Hoover Institution. Much of the research for this paper was conducted while Davis was a National Fellow at the Hoover Institution. 


\section{References}

Abowd, John and Arnold Zellner (1985) "Estimating Gross Labor Force Flows," Journal of Economic and Business Statistics, 9, 254-283.

Abraham, K. and L. Katz (10S6) "Cyclical Unemployment: Sectoral Shifts or Aggregate Disturbances?" Journal of Political Economy, 94, 507-522.

Akerlof, George, Andrew Rose, and Janet Yellen (1988) "Job Switching and Job Satisfaction in the U.S. Labor Market," Brookings Papers on Economic Activity, 1988:2, 495-582.

Baldwin, John R. and Paul K. Gorecki (1990) Structural Change and the Adjustment Process: Perspectives on Firm Growth and Worker Turnover, Canadian Government Publishing Centre, Ottawa.

Blanchard, Olivier and Peter Dianond (19S9) "The Beveridge Curve" Brookings Papers on Economic Activity 1989:1, 1-60.

Blanchard, Olivier and Peter Diamond (1990) "The Cyclical Behavior of Gross Flows of Workers in the U.S."" Brookings Papers on Economic Activity 1990: 2, 85-155.

Bresnahan, Timothy and Daniel Raff (1090) "Technological Heterogeneity, Adjustment Costs, and the Dynamics of Plant Shut-Down Behavior: The American Motor Vehicle Industry in the Time of the Great Depression," working paper, Stanford University.

Bronars, Stephen G. (1990) "Employment and Hours Variation Over the Business Cycle," paper in progress, Bureau of Labor Statistics.

Caballero, Ricardo (1990) "A Fallacy of Composition" Discussion Paper Series No. 479, Columbia University.

Clark, Kim B. and Lawrence H. Summers (1979) "Labor Market Dynamics and Unemployment: A Reconsideration," Brookings Papers on Economic Activity, 1979:2, 13-60.

Darby, Michael, John Haltiwanger, and Mark Plant (10S5) "Unemployment Rate Dynamics and Persistent Unemployment under Rational Expectations," American Economic Review, 75, 614-637.

Davis, Steve J. (1987) "Fluctuations in the Pace of Labor Reallocation," CarnegieRochester Conference Series on Public Policy, 27, 335-402.

Davis, Steve J. and John Haltiwanger (1989) "Gross Job Creation, Gross Job Destruction, and Employment Reallocation," Hoover Institution Working Papers in Economics, E-89-33.

Davis, Steve J. and John Haltiwanger (1990) "Gross Job Creation and Destruction: Microeconomic Evidence and Macroeconomic Implications," NBER Macroeconomics Annual, 5, 123-168. 
Davis, Steve J., John Haltiwanger, and Scott Schuh (1990) "Published Versus Sample Statistics from the ASM: Implications for the LRD" forthcoming in Proceedings of the American Statistical Association, Business and Economics Statistics Section.

Dunne, Timothy and Mark J. Roberts (1989) "The Duration of Employment Opportunities in U.S. Manufacturing," working paper, Pennsylvania St. University.

Dunne, Timothy, Mark J. Roberts, and Larry Samuelson (1989a) "The Growth and Failure of U.S. Manufacturing Plants," Quarterly Journal of Economics, 104, 671-698.

Dunne, Timothy, Mark J. Roberts, and Larry Samuelson (1989b) "Plant Turnover and Gross Employment Flows in the U.S. Manufacturing Sector," Journal of Labor Economics, 7 , no. $1,48-71$

Ericson, Richard and Ariel Pales (19S9) "An Alternative Theory of Firm and Industry Dynamics," working paper, Yale University.

Evans, David S. (1987a) "Tests of Alternative Theories of Firm Growth," Journal of Political Economy, 95, no. 4, 657-074.

Evans, David S. (1987b) "The Relationship between Firm Growth, Size and Age: Estimates for 100 Manufacturing Industries," Journal of Industrial Economics, 15, 567581.

Hall, Bronwyn H. (1987) "The Relationship between Firm Size and Firm Growth in the U.S. Manufacturing Sector," Journal of Industrial Economics, 15, 583-606.

Hall, Robert E. (1979) "A Theory of the Natural Unemployment Rate and the Duration of Employment," Journal of Monetary Economics, 5, 153-169.

Hall, Robert E. (1982) "The Importance of Lifetime Jobs in the U.S. Economy," American Economic Review, 72, 716-724.

Johnson, G.E. and P.R.G. Layard (1986) "The Natural Rate of Unemployment: Explanation and Policy," in O. Ashenfelter and Layard, eds., Handbook of Labor Economics, Volume 2, Amsterdam: North-Holland.

Jovanovic, Boyan (1982) "Selection and the Evolution of Industry," Econometrica, 50, 3, 649-670.

Lambson, Val E. (1989) "Industry Evolution with Sunk Costs and Uncertain Market Conditions," forthcoming in the International Journal of Industrial Organization.

Leonard, Jonathan (1987) "In the Wrong Place at the Wrong Time: The Extent of Frictional and Structural Unemployment." in Unemployment $\&$ the Structure of Labor Markets, edited by Kevin Lang and J. Leonard, Basil Blackwell: New York.

Lilien, David (1980) "The Cyclical Pattern of Temporary Layoffs in United States Manufacturing," Review of Economics and Statistics, 112, no. 1, 24-31. 
Lilien, David (1982) "Sectoral Shifts and Cyclical Unemployment," Journal of Political Economy, 90, 777-793.

Lippman, S.A. and R.P. Rumelt (1982) "Uncertain Imitability: An Analysis of Interfirm Differences Under Competition," Bell Journal of Economics, 19, no. 2, 418-438.

Pakes, Ariel and Richard Ericson (1990) "Empirical Implication of Alternative Models of Firm Dynamics," working paper, Yale University.

Phelps, Edmund S., et al. (1970) Microeconomic Foundations of Employment and Inflation Theory, New York: Norton.

Poterba, James and Lawrence Summers (19S9) "Reporting Errors and Labor Market Dynamics," Econometrica, 54, 1319-1338.

Regev, Haim (1990), unpublished tabulations from Central Statistical Bureau, Israel. 
Furs 4

Unmiond crowh Ralo Dutbouten

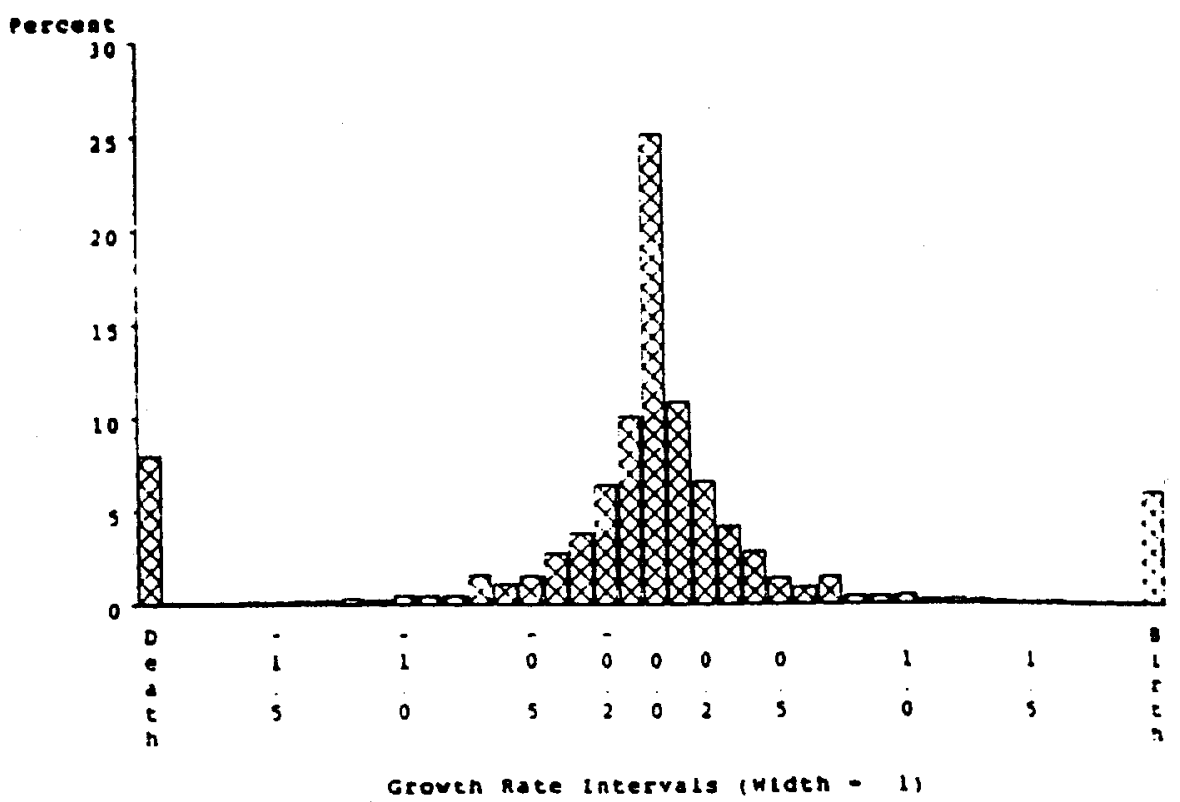

Figre 18

Slze-Waighed Gowth Ralo Datribution

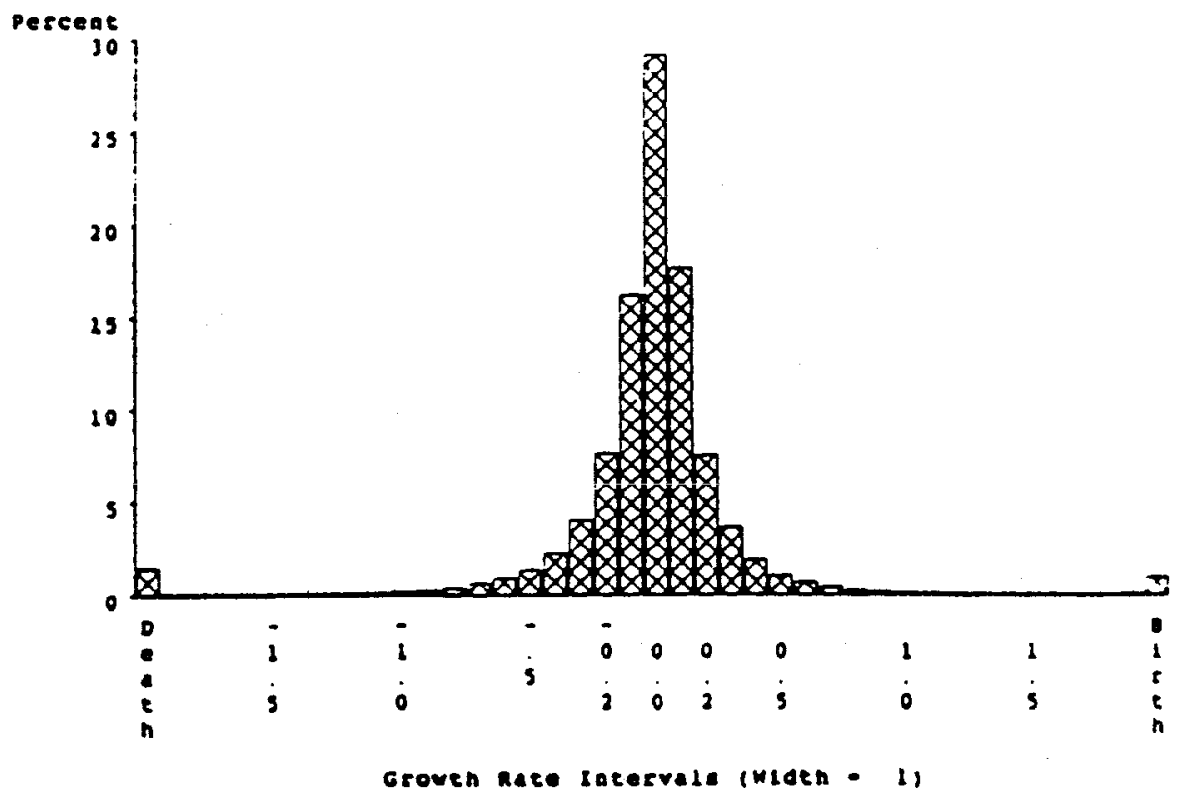




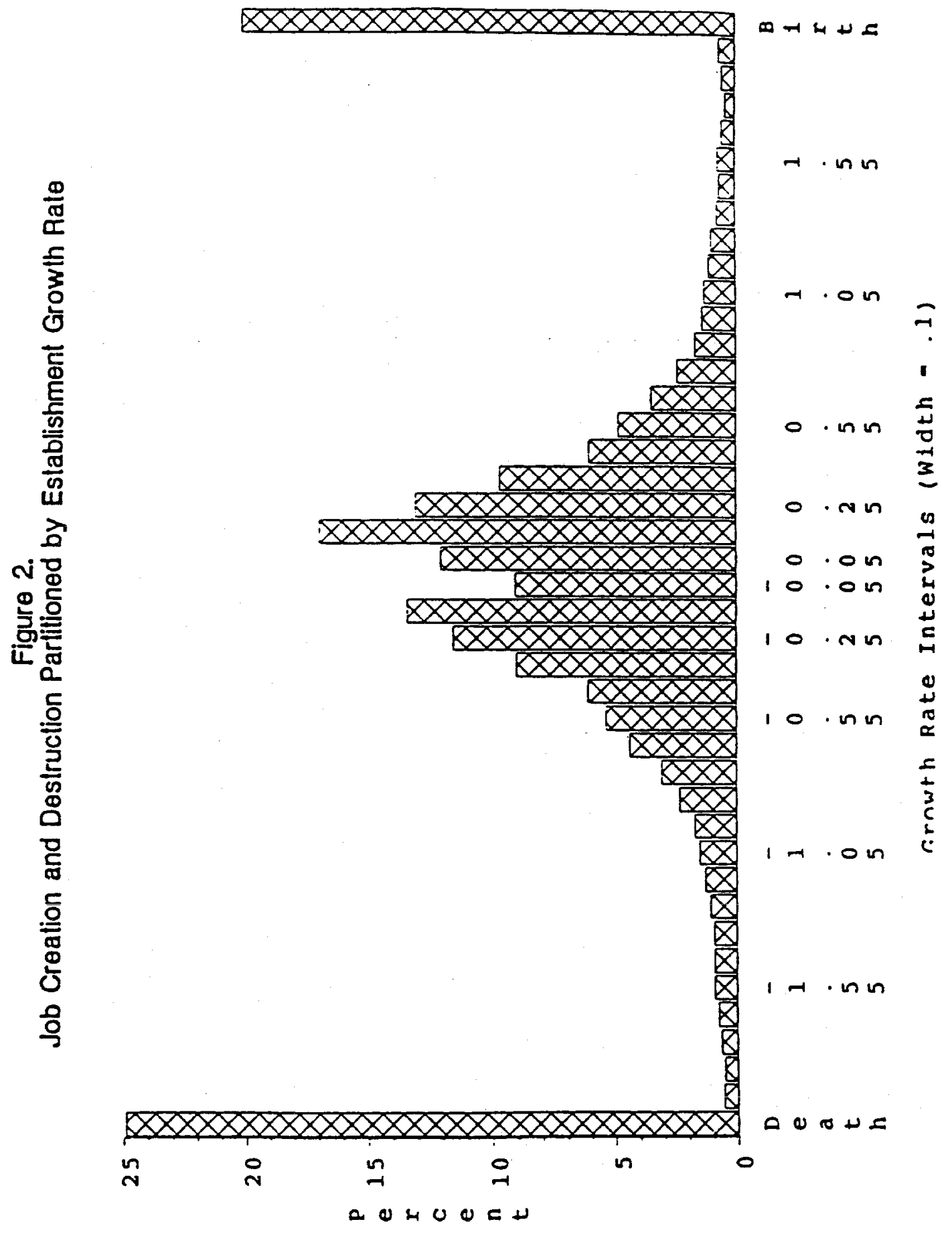


Table 1. Net and Gross Rates by Year, Manufacturing Sector

\begin{tabular}{|c|c|c|c|c|c|}
\hline Year & $P_{\text {OS }}$ & $N E G_{t}$ & $N E T_{t}^{1}$ & SUM, & MAX, \\
\hline $\begin{array}{l}1973 \\
1975 \\
1976 \\
1977 \\
1978 \\
1980 \\
1981 \\
1982 \\
1983 \\
1985 \\
1986\end{array}$ & $\begin{array}{l}0.132 \\
0.067 \\
0.113 \\
0.112 \\
0.116 \\
0.080 \\
0.070 \\
0.064 \\
0.086 \\
0.084 \\
0.088\end{array}$ & $\begin{array}{l}0.061 \\
0.166 \\
0.096 \\
0.096 \\
0.075 \\
0.093 \\
0.118 \\
0.152 \\
0.142 \\
0.117 \\
0.132\end{array}$ & $\begin{array}{l}0.071 \\
-0.100 \\
0.017 \\
0.018 \\
0.041 \\
-0.012 \\
-0.049 \\
-0.087 \\
-0.056 \\
-0.033 \\
-0.044\end{array}$ & $\begin{array}{l}0.194 \\
0.233 \\
0.209 \\
0.206 \\
0.191 \\
0.173 \\
0.188 \\
0.216 \\
0.227 \\
0.201 \\
0.220\end{array}$ & $\begin{array}{l}0.133 \\
0.166 \\
0.122 \\
0.117 \\
0.117 \\
0.102 \\
0.119 \\
0.152 \\
0.143 \\
0.121 \\
0.133\end{array}$ \\
\hline
\end{tabular}

Notes:

${ }^{N} N E T_{t} \equiv P O S_{t}-N E G_{t}$ is the net employment growth rate.

2 Marginal significance level in parentheses.

Table 3. Persistence Rates for Job Creation and Destruction ${ }^{1}$

$\begin{array}{lllll}\text { Year }^{2}(t) & F P O S_{t 1} & F P O S_{12} & F N E G_{t 1} & F N E G_{\imath 2} \\ 1975 & .73 & .54 & .72 & .62 \\ 1976 & .75 & .58 & .79 & .69 \\ 1977 & .76 & - & .79 & - \\ 1980 & .63 & .43 & .82 & .77 \\ 1981 & .60 & .44 & .88 & .82 \\ 1982 & .60 & - & .86 & - \\ 1985 & .63 & - & .84 & - \\ \text { Simple Mean } & .67 & .50 & .81 & .73\end{array}$

Notes: $F P O S_{1 n}\left(F N E G_{1 n}\right)$ is the fraction of jobs created (destroyed) between March of year $t-1$ and March of year $t$ that persists through March of year $t+n$.

${ }^{2}$ Given the ASM panel structure, the persistence measures can be calculated for all plants only in the indicated years. 
TABTE 2

Net and Gross Rates by Industry

Size-Heighted Averages: 1

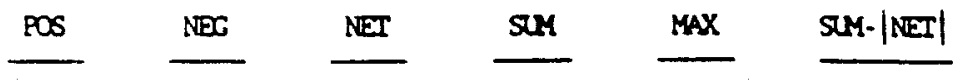

Industry:

\begin{tabular}{|c|c|c|c|c|c|c|c|}
\hline Food & $(20)$ & 0.089 & 0.104 & -0.015 & 0.193 & 0.108 & 0.169 \\
\hline Tobacco & (21) & 0.058 & 0.082 & -0.024 & 0.140 & 0.090 & 0.098 \\
\hline Textile & (22) & 0.074 & 0.110 & -0.036 & 0.185 & 0.124 & 0.121 \\
\hline Apparel & (23) & 0.116 & 0.156 & -0.040 & 0.272 & 0.168 & 0.207 \\
\hline Luber & (24) & 0.129 & 0.160 & -0.031 & 0.288 & 0.188 & 0.202 \\
\hline Anmiare & (25) & 0.101 & 0.121 & -0.019 & 0.222 & 0.143 & 0.157 \\
\hline Paper & (26) & 0.063 & 0.078 & -0.015 & 0.141 & 0.089 & 0.105 \\
\hline Printing & (27) & 0.091 & 0.087 & -0.004 & 0.178 & 0.099 & 0.158 \\
\hline Chemicals & (28) & 0.068 & 0.080 & -0.013 & 0.148 & 0.089 & 0.118 \\
\hline Petrolem & (29) & 0.066 & 0.091 & -0.025 & 0.157 & 0.100 & 0.114 \\
\hline Rubber & (30) & 0.107 & 0.118 & -0.011 & 0.225 & 0.143 & 0.163 \\
\hline Leather & (31) & 0.091 & 0.144 & -0.053 & 0.235 & 0.152 & 0.166 \\
\hline \multicolumn{8}{|l|}{ Stane, Clay } \\
\hline and Glass & (32) & 0.093 & 0.123 & -0.031 & 0.216 & 0.136 & 0.160 \\
\hline \multicolumn{8}{|c|}{ Fabricaced } \\
\hline Mecals & $(34)$ & 0.095 & 0.120 & -0.025 & 0.215 & 0.137 & 0.156 \\
\hline $\begin{array}{l}\text { Norelectric } \\
\text { Machinery }\end{array}$ & (35) & 0.096 & 0.121 & -0.025 & 0.217 & 0.141 & 0.152 \\
\hline \multicolumn{8}{|l|}{ Electric } \\
\hline Machinery & (36) & 0.097 & 0.109 & -0.011 & 0.206 & 0.130 & 0.152 \\
\hline Transportation & (37) & 0.094 & 0.099 & .0 .006 & 0.193 & 0.123 & 0.140 \\
\hline Instrments & (38) & 0.093 & 0.093 & -0.002 & 0.186 & 0.112 & 0.149 \\
\hline Miscellareous & (39) & 0.108 & 0.145 & -0.037 & 0.253 & 0.156 & 0.193 \\
\hline \multicolumn{8}{|c|}{ Total } \\
\hline Manufactring & & 0.092 & 0.113 & -0.021 & 0.205 & 0.129 & 0.152 \\
\hline \multicolumn{8}{|l|}{ Size-weighted } \\
\hline Standard & & & & & & & \\
\hline Deviactor & & 0.016 & 0.21 & 0.015 & $0.03 / 4$ & 0.023 & 0.028 \\
\hline
\end{tabular}

Cross-Industoy: ${ }^{2} \quad \rho$ (ROS.NES) $=0.764 \quad \rho$ (NET, SUM -0.347

$(0.0001) \quad(0.135)$

1size-weighiced average based on anual values with $t$ - 1973-1986 (excluding 1974, 1979. 1984).

Harginal sigrificance levels in parencheses. 
Table 4. Net and Gross Rates by Type of Plant

\begin{tabular}{|c|c|c|c|c|c|c|}
\hline $\begin{array}{l}\text { No. of Employees } \\
1-99 \\
100-249 \\
250-499 \\
500-999 \\
1000+\end{array}$ & $\begin{array}{l}\text { POS } \\
.140 \\
.099 \\
.086 \\
.070 \\
.060\end{array}$ & $\begin{array}{l}N E G \\
.164 \\
.120 \\
.105 \\
.093 \\
.078\end{array}$ & $\begin{array}{l}S^{S i z \mathrm{e}^{2}} \\
\quad N E T \\
-.023 \\
-.021 \\
-.019 \\
-.023 \\
-.019\end{array}$ & $\begin{array}{l}S U M \\
.304 \\
.219 \\
.191 \\
.163 \\
.138\end{array}$ & $\begin{array}{l}M A X \\
.180 \\
.133 \\
.120 \\
.106 \\
.090\end{array}$ & $\begin{array}{l}\text { Share } \\
.246 \\
.185 \\
.162 \\
.134 \\
.273\end{array}$ \\
\hline 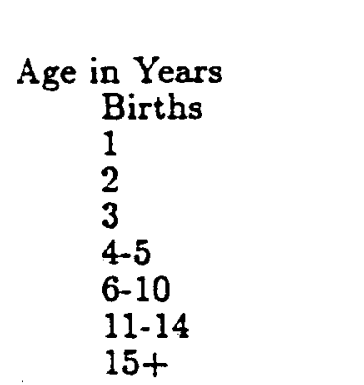 & $\begin{array}{l}\text { POS } \\
.270 \\
.169 \\
.139 \\
.133 \\
.120 \\
.102 \\
.065\end{array}$ & $\begin{array}{l}N E G \\
.206 \\
.167 \\
.117 \\
.134 \\
.121 \\
.111 \\
.097\end{array}$ & $\begin{array}{l}\text { Age } \\
N E T \\
\\
.064 \\
.003 \\
.022 \\
-.001 \\
-.001 \\
-.010 \\
-.033\end{array}$ & $\begin{array}{l}S U M \\
.476 \\
.336 \\
.257 \\
.267 \\
.240 \\
.213 \\
.162\end{array}$ & $\begin{array}{l}\text { MAX } \\
.299 \\
.200 \\
.148 \\
.154 \\
.135 \\
.123 \\
.103\end{array}$ & $\begin{array}{l}\text { Share } \\
.008 \\
.018 \\
.015 \\
.015 \\
.045 \\
.143 \\
.110 \\
.645\end{array}$ \\
\hline $\begin{array}{l}\text { Firm Operates: } \\
\text { Multiple Mfg. Plants } \\
\text { A Single Mfg. Plant }\end{array}$ & $\begin{array}{l}\text { POS } \\
.080 \\
.131\end{array}$ & $\begin{array}{l}\text { Ow } \\
N E G \\
.103 \\
.146\end{array}$ & $\begin{array}{c}\text { ship Ty } \\
N E T \\
-.023 \\
-.016\end{array}$ & $\begin{array}{l}S U M \\
.184 \\
.277\end{array}$ & $\begin{array}{l}M A X \\
.115 \\
.170\end{array}$ & $\begin{array}{l}\text { Share } \\
.768 \\
.232\end{array}$ \\
\hline $\begin{array}{l}\text { Census Region } \\
\text { New England } \\
\text { Middle Atlantic } \\
\text { South Atlantic } \\
\text { E. South Central } \\
\text { W. South Central } \\
\text { E. North Central } \\
\text { W. North Central } \\
\text { Mountain } \\
\text { Pacific }\end{array}$ & $\begin{array}{l}\text { POS } \\
.090 \\
.085 \\
.079 \\
.092 \\
.092 \\
.091 \\
.105 \\
.118 \\
.118\end{array}$ & $\begin{array}{l}\text { Geog } \\
N E G \\
.108 \\
.121 \\
.111 \\
.107 \\
.101 \\
.107 \\
.115 \\
.114 \\
.128\end{array}$ & $\begin{array}{l}\text { hic Re } \\
N E T \\
-.018 \\
-.036 \\
-.032 \\
-.015 \\
.009 \\
-.016 \\
-.010 \\
.005 \\
-.009\end{array}$ & $\begin{array}{l}S U M \\
.198 \\
.205 \\
.190 \\
.198 \\
.193 \\
.198 \\
.220 \\
.232 \\
.246\end{array}$ & $\begin{array}{l}M A X \\
.122 \\
.127 \\
.126 \\
.122 \\
.117 \\
.124 \\
.134 \\
.138 \\
.149\end{array}$ & $\begin{array}{l}\text { Share } \\
.073 \\
.175 \\
.238 \\
.068 \\
.154 \\
.070 \\
.077 \\
.026 \\
.120\end{array}$ \\
\hline
\end{tabular}

Notes:

1 Figures are size-weighted averages of eleven annual values, except for age group figures. Age group figures are size-weighted averages of 1978 and 1983 values.

2 A plant's size is measured as its mean number of employees over all sample observations with positive employment.

${ }^{2}$ Group share of total employment, using the size metric described in the text. 
Table 5. Estimated Fraction of Job Reallocation Due to Learning about Initial Conditions

$\begin{array}{lll} & n=4 & n=6 \\ \text { Total Manufacturing } & .11 & .13 \\ \text { Selected Industries } & & \\ \text { Food } & .10 & .11 \\ \text { Tobacco } & .02 & .02 \\ \text { Printing } & .17 & .19 \\ \text { Primary Metals } & .05 & .05 \\ \text { Fabricated Metals } & .11 & .13 \\ \text { Transportation } & .08 & .10 \\ \text { Selected Regions } & & \\ \text { Middle Atlantic } & .10 & .11 \\ \text { South Atlantic } & .08 & .10 \\ \text { Pacific } & .14 & .16 \\ \text { Size Classes } & & \\ \text { 0-99 employees } & .18 & .21 \\ \text { 100-249 } & .08 & .09 \\ \text { 250-499 } & .09 & .09 \\ \text { 500-999 } & .06 & .07 \\ \text { 1000t } & .03 & .04 \\ \text { Ownership Type } & & .20 \\ \text { Single Plant } & .17 & .10 \\ \text { Multiple Plants } & .08 & \end{array}$

Note:

(1) All table entries are based on equation (2) in the text using pooled sample data for 1978 and 1983. (2) The table shows entries for selected industries and regions, including the extremes. 
Table 6. Estimated Fraction of Cross-Sectoral Variation in Job Reallocation Rates Due to Learning about Initial Conditions

Cross-Sectoral Standard

Sectoral Classification by:

Deviation of Job

Reallocation Rates

Industry Region Size Ownership

Fraction of Cross-Sectoral

.042

.026

.056

.050

Variance Explained by

Learning About Initial

Conditions, Assuming $n=4$

.32

.39

.51

.56

Fraction of Cross-Sectoral

Variance Explained by

Learning About Initial

Conditions, Assuming $n=6$

.36

.48

.57

.62

Notes:

(1) All table entries are based on the pooled sample data for 1978 and 1983.

(2) Rows two and three report the quantitiy $1-(\bar{V} / V) . V$ is defined as the cross-

sectoral variance of job reallocation rates. $\bar{V}$ is defined as the cross-sectoral variance of adjusted job reallocation rates. The adjusted sectoral reallocation rate equals the observed rate minus the contribution of learning as estimated from equation (2). 
Table 7. Fraction of Excess Job Reallocation Due to Between-Group Employment Shifts, Means of 1978 and 1983 Values by Two-Digit Industry

\begin{tabular}{|c|c|c|c|c|c|}
\hline $\begin{array}{l}\text { Group Type } \\
\text { No. of Groups }\end{array}$ & ${ }_{8}^{\text {Age }}$ & $\begin{array}{l}\text { Size } \\
5\end{array}$ & $\begin{array}{l}\text { Region } \\
9\end{array}$ & $\begin{array}{l}\text { Ownership } \\
2\end{array}$ & $\begin{array}{l}\text { All' } \\
720\end{array}$ \\
\hline \multicolumn{6}{|l|}{ Industry } \\
\hline Food & .13 & .01 & & & $\begin{array}{r}.36 \\
62\end{array}$ \\
\hline Tobacco & .12 & .03 & .05 & $\begin{array}{l}.01 \\
.03\end{array}$ & $\begin{array}{l}62 \\
39\end{array}$ \\
\hline Textiles & .18 & .01 & .01 & .03 & .39 \\
\hline Apparel & .20 & .11 & .10 & .02 & .46 \\
\hline Lumber & .01 & .00 & .02 & .00 & .36 \\
\hline Furniture & .08 & .03 & .04 & .00 & .45 \\
\hline Paper & .12 & .08 & .08 & .00 & .43 \\
\hline Printing & .08 & .06 & .05 & .00 & .39 \\
\hline Chemicals & .06 & .00 & .00 & .00 & .39 \\
\hline Petroleum & .26 & .07 & .21 & .00 & .65 \\
\hline Rubber & .16 & .12 & .01 & .00 & .48 \\
\hline Leather & .12 & .03 & .06 & .01 & .52 \\
\hline Stone, Clay, Glass & .04 & .00 & .02 & .00 & .39 \\
\hline Primary Metals & .07 & .01 & .05 & .00 & .31 \\
\hline Fabricated Metals & .05 & .00 & .00 & .00 & .23 \\
\hline Nonelectric Mach. & .12 & .00 & .00 & .00 & .31 \\
\hline Electric Machinery & .10 & .00 & .02 & .00 & .33 \\
\hline Transportation & .09 & .00 & .01 & .00 & .35 \\
\hline Instruments & .11 & .00 & .02 & .00 & .50 \\
\hline Miscellaneous & .20 & .05 & .05 & .06 & 60 \\
\hline
\end{tabular}

Means of 1978 and 1983 Values for Total Manufacturing

$\begin{array}{lllllllll}\begin{array}{l}\text { Group } \\ \text { Type }\end{array} & \text { Age } & \text { Size } & \text { Region } & \begin{array}{l}\text { Owner- } \\ \text { ship }\end{array} & \begin{array}{l}\text { 2-Digit } \\ \text { Ind. }\end{array} & \begin{array}{l}\text { 4-Digit } \\ \text { Ind }\end{array} & \begin{array}{l}\text { All, } \\ \text { ex. Ind.' }\end{array} & \text { All }^{2} \\ \text { Number } & 8 & 5 & 9 & 2 & 20 & 450 & 720 & 14400^{3} \\ & .06 & .00 & .00 & .00 & .01 & .12 & .15 & .39\end{array}$

Notes:

1 Based on a grouping of plants by age. size, region. and ownership type simultaneously.

${ }^{2}$ Based on a grouping of plants by age, size, region. ownership type, and two-digit industry simultaneously.

${ }^{3}$ Approximately 11,000 group cells are nonempty. 
Table 8. Decomposition of Time-Series Variance of Job Reallocation, Creation and Destruction Sectoral Classification Scheme

$\begin{array}{llllllll} & \text { Total. } & \text { 4-digit } & \text { 2-digit } & \begin{array}{l}\text { 2-digit, } \\ \text { Size }\end{array} & \begin{array}{l}\text { 2-digit, } \\ \text { Age }\end{array} & \begin{array}{l}\text { 2-digit, } \\ \text { Owner }\end{array} & \begin{array}{l}\text { 2-digit, } \\ \text { \# }\end{array} \\ \text { \# of Sectorsion }\end{array}$

Fraction of Job Reallocation Variance $\left(S U M_{t}\right.$ ) Accounted for by:

\begin{tabular}{|c|c|c|c|c|c|c|c|}
\hline $\begin{array}{l}\text { (a) sectoral/agg. } \\
\text { mean effects }\end{array}$ & 0.03 & 0.105 & 0.044 & 0.044 & 0.042 & 0.051 & 0.053 \\
\hline $\begin{array}{l}\text { (b) idiosyncratic } \\
\text { effects }\end{array}$ & 1.026 & 0.797 & 0.876 & 0.816 & 0.879 & 0.838 & 0.917 \\
\hline $2 \operatorname{Cov}(a, b)$ & -0.056 & 0.098 & 0.079 & 0.140 & 0.078 & 0.111 & 0.030 \\
\hline
\end{tabular}

Fraction of Job Creation Variance (POS ) Accounted for by:

\begin{tabular}{|c|c|c|c|c|c|c|c|}
\hline $\begin{array}{l}\text { (a) sectoral/agg. } \\
\text { mean effects }\end{array}$ & 1.44 & 1.318 & 1.395 & 1.431 & 1.388 & 1.459 & 1.385 \\
\hline $\begin{array}{l}\text { (b) idiosyncratic } \\
\text { effects }\end{array}$ & 0.16 & 0.124 & 0.136 & 0.142 & 0.138 & 0.149 & 0.142 \\
\hline $2 \operatorname{Cov}(a, b)$ & -0.60 & -0.442 & -0.531 & -0.573 & -0.526 & -0.609 & -0.526 \\
\hline
\end{tabular}

Fraction of Job Destruction Variance (NEG ) Accounted for by:

$\begin{array}{llllllll}\text { (a) sectoral/agg. } & 0.63 & 0.705 & 0.658 & 0.726 & 0.664 & 0.680 & 0.665\end{array}$ mean effects

$\begin{array}{llllllll}\text { (b) idiosyncratic } & 0.079 & 0.062 & 0.068 & 0.063 & 0.067 & 0.066 & 0.071\end{array}$ effects

$\begin{array}{llllllll}2 \operatorname{Cov}(\mathrm{a}, \mathrm{b}) & 0.287 & 0.233 & 0.274 & 0.211 & 0.288 & 0.254 & 0.264\end{array}$

Notes:

(1) Entries in the top panel are based on the variance decomposition in equation (9). Each entry reports the ratio of the indicated term on the right side of (9) to the term on the left side. Entries in the second and third panels are based on analogous variance decompositions for job creation and destruction.

(2) Size, region and ownership sectors are defined as in Tables 4-6.

(3) There are two age groups: young plants (0-9 years) and old plants ( $10+$ years). 
Table 9. Cyclical Behavior of Sectoral Job Reallocation Rates:

Time-Series Correlations Between NET, and Job Reallocation Measures

\section{Sectoral Classiflcation Scheme}

Total. 4-digit 2-digit 2-digit, 2-digit, 2-digit, 2-digit, Mfg. Size Age Owner Region

Summary Statistics on Correlations of NET, with SUM $M_{\mathrm{st}}$ :

\begin{tabular}{|c|c|c|c|c|c|c|c|}
\hline $\begin{array}{l}\text { Size-weighted } \\
\text { Avg. Correlation }\end{array}$ & -0.57 & .0 .35 & -0.51 & -0.37 & -0.49 & -0.39 & -0.39 \\
\hline$(\#<0) /$ Total & $1 / 1$ & $363 / 450$ & $20 / 20$ & $85 / 100$ & $27 / 40$ & $29 / 40$ & $146 / 177$ \\
\hline \multicolumn{8}{|c|}{ Summary Statistics on Correlations of NET, with $\widehat{S U M}{ }_{31}^{S T}$ : } \\
\hline ize-Weighted & -0.64 & -0.36 & -0.55 & .0 .41 & .0 .50 & -0.45 & -0.42 \\
\hline $\begin{array}{l}\text { Avg. Correlatio } \\
(\#<0) / \text { Total }\end{array}$ & $1 / 1$ & $360 / 450$ & $20 / 20$ & $s 7 / 100$ & $29 / 40$ & $31 / 40$ & $152 / 177$ \\
\hline
\end{tabular}

\section{Sector Type}

Durable Nondur. Two-Digit Industry by:

Small Large Young Old Single Multi

Summary Statistics on Correlations of NET st with SUM, :

\begin{tabular}{|c|c|c|c|c|c|c|c|c|}
\hline Size-weighted & -0.61 & -0.35 & -0.13 & -0.61 & -0.08 & -0.70 & -0.09 & -0.48 \\
\hline $\begin{array}{l}\text { Avg. Correlation } \\
(\#<0) / \text { Total }\end{array}$ & $10 / 10$ & $10 / 10$ & $31 / 40$ & $37 / 40$ & $7 / 20$ & $20 / 20$ & $10 / 20$ & $19 / 21$ \\
\hline Summary Statis & ics on & irelatio & of $N E$ & with $S$ & $n_{3 t}$ & & & \\
\hline ze-weighted & -0.65 & -0.40 & -0.20 & -0.63 & 0.06 & -0.71 & -0.19 & 0.53 \\
\hline $\begin{array}{l}\text { vg. Correlation } \\
\#<0) / \text { Total }\end{array}$ & $10 / 10$ & $10 / 10$ & $33 / 40$ & $38 / 40$ & $9 / 20$ & $20 / 20$ & $11 / 20$ & $20 / 2$ \\
\hline
\end{tabular}

Notes:

(1) Sectors are defined as in Table 8.

(2) "Small" refers to the forty sectors with plants in the 0-99 and 100-249 size classes.

"Large" refers to the forty sectors with plants in 500-999 and 1000+ size classes. 
Table 10. Regressions of Adjusted Sectoral Job Reallocation Rates on Own-Sector and Manufacturing Net Growth Rates

Dependent Variable in Regressions: Adjusted Sectoral Job Reallocation Rates

\section{Summary of Regressions and Goodness-of-Fit Measures}

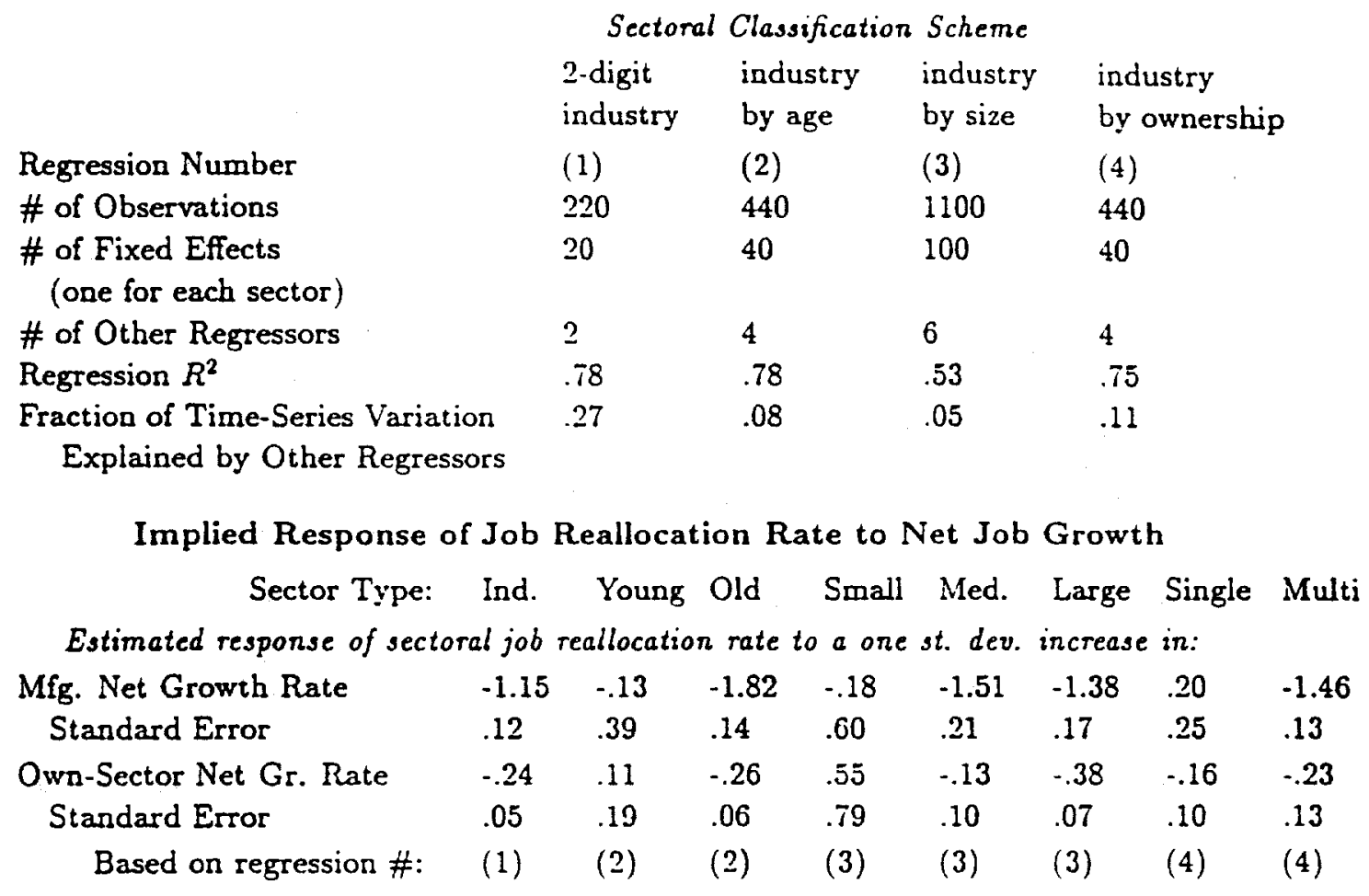

Notes:

(1) In regression (1), "other regressors" refers to the manufacturing net growth rate $\left(g_{t}\right)$ and the own-sector net growth rate deviated about the manufacturing growth rate (got). Relative to regression (1): regression (2) adds interactions of these variables with one age-group dummy; regression (3) adds interactions with two size-class dummies; and regression (4) adds interactions with one ownership-class dummy.

(2) Time-series variation equals the residual variation after eliminating sectoral fixed effects. Regressing this residual variation on the "other regressors" yields the entries titled "Fraction of Time-Series Variation Explained by Other Regressors."

(3) Estimated responses in the bottom panel are multiplied by 100.

(4) In computing the estimated responses in the bottom panel, a one standard deviation increase in the own-sector net growth rate is measured as the size-weighted average of the time-series standard deviations of sectoral growth rates. This measure isolates the magnitude of time-series variation in the g.t.

(5) The standard errors in the bottom panel are heteroscedasticity consistent. 